\title{
Basic Reproduction Rate and Case Fatality Rate of COVID-19: Application of Meta-analysis
}

\author{
Suryakant Yadav ${ }^{1}$, Pawan Kumar Yadav ${ }^{2}$ \\ ${ }^{1}$ Assistant Professor, Department of Development Studies, International Institute for Population Sciences, \\ Mumbai. (Email: suryakant_yadav@iips.net; suryakant11@gmail.com)
}

${ }^{2}$ Research Scholar, International Institute for Population Sciences, Mumbai. (Email: pawankumaryadavbhu@gmail.com)

All the correspondence may be sent to emails: suryakant_yadav@iips.net; suryakant11@gmail.com.

\section{Research Highlights}

1. The robust estimate of Basic Reproduction Rate ( $\left.R_{0}\right)$ of COVID-19 based on a meta-analysis performed on the pieces of evidence available across countries is 3.11 (2.49-3.71) persons for a generalised population in the absence of any control measures

2. The robust estimate of Case Fatality Rate (CFR) based on a meta-analysis performed on the pieces of evidence available across countries equals to 2.56 (2.063.05) per cent for a generalised population in approximately one-and-a-half months from the onset of the disease COVID-19.

3. A significant regional variation is evident for the Basic Reproduction Rate $\left(\mathbf{R}_{0}\right)$ but not for the Case Fatality Rate (CFR)

4. The peer-reviewed articles with a small sample size do not suffer from publication bias in a meta-analysis of COVID-19.

\section{Added Value of this Study}

Out study combine available evidence of the parameter values, such as reproduction rate and case fatality rate, of the generalised epidemiological models for coronavirus disease of 2019 (COVID-19). In this way, we have reduced the dependency on data from a particular region or time or a homogeneous population. By applying meta-analysis, we estimated the robust estimate of reproduction rate and case fatality rate, which is applicable across heterogeneous populations. We proclaim that the reproduction rate of COVID-19 varies across subgroups of populations and regions and periods, but the case fatality rate remained the same. These estimates of reproduction rate and case fatality rate are worthwhile for

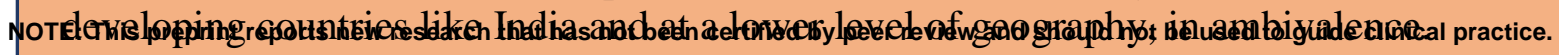



medRxiv preprint doi: https://doi.org/10.1101/2020.05.13.20100750; this version posted May 16,2020 . The copyright holder for this preprint
(which was not certified by peer review) is the author/funder, who has granted medRxiv a license to display the preprint in perpetuity. It is made available under a CC-BY-ND 4.0 International license .

\begin{abstract}
Background: The outbreak of novel coronavirus disease of 2019 (COVID-19) has a wider geographical spread than other previous viruses such as Ebola and H1N1. The onset of disease and its transmission and severity has become a global concern. The policymakers have a serious concern for containing the spread and minimising the risk of death.
\end{abstract}

Aim: This study aims to provide the estimates of basic reproduction rate $\left(\mathrm{R}_{0}\right)$ and case fatality rate (CFR) which applies to a generalised population.

Methods: A systematic review was carried out to retrieve the published estimates of reproduction rate and case fatality rate in peer-reviewed articles from PubMed MEDLINE database with defined inclusion and exclusion criteria in the period 15 December 2019 to 3 May 2020. The systematic review led to the selection of 24 articles for $\mathrm{R}_{0}$ and 17 articles for CFR. These studies used data from China and its provinces, other Asian countries such as Japan, Korea, the Philippines, and countries from other parts of the world such as Nigeria, Iran, Italy, Europe as a whole, France, Latin America, Turkey, the United Kingdom (UK), and the United States of America (USA). These selected articles gave an output of 30 counts of $\mathrm{R}_{0}$ and 29 counts of CFR which were used in a meta-analysis. A meta-analysis, with the inverse variance method, fixed- and random-effects model and the Forest plot, was performed to estimate the mean effect size or mean value of basic reproduction rate and case fatality rate. The Funnel plot is used to comprehend the publication bias.

Results: We estimated the robust estimate of $\mathrm{R}_{0}$ at 3.11 (2.49-3.71) persons and the robust estimate of CFR at 2.56 (2.06-3.05) per cent after accounting for heterogeneity among studies, using the random-effects model. The regional subgroup analysis in a meta-analysis was significant for $\mathrm{R}_{0}$ but was not significant for $\mathrm{CFR}$. The $\mathrm{R}_{0}$ values varied from 1.90 (1.06-2.74) persons to 3.83 (2.44-5.22) persons across the regions. The Funnel plot confirms that the selected studies are significant at one per cent level of significance.

Conclusion: We found that one person is likely to infect two to three persons in the absence of any control measures, and around three per cent of the population are at the risk of death within one-and-a-half months from the onset of disease COVID-19 in a generalised population. The emergence of SARS-CoV-2 varies across regions, but the risk of death remains the same.

Contribution: The estimates of $\mathrm{R}_{0}$ and CFR are independent of data from a particular region or time or a homogeneous population. These estimates are applicable to a generalised population. Therefore, the estimates of $\mathrm{R}_{0}$ and $\mathrm{CFR}$ are unequivocally applicable to developing country like India and its states or districts, in ambivalence. The assessments of $\mathrm{R}_{0}$ and CFR values across the developed nations make all of us aware of consequences of COVID-19, and hence these estimates are of crucial importance for government authorities for the practical implementation of strategies and control measures to contain the disease.

Keywords: Covid-19, SARS-CoV-2, Reproduction Rate, Case Fatality Rate, Systematic Review, Meta-analysis 
medRxiv preprint doi: https://doi.org/10.1101/2020.05.13.20100750; this version posted May 16, 2020. The copyright holder for this preprint

(which was not certified by peer review) is the author/funder, who has granted medRxiv a license to display the preprint in perpetuity. It is made available under a CC-BY-ND 4.0 International license.

\section{Introduction}

The outbreak and spread of novel coronavirus-2019, particularly identified as Severe Acute Respiratory Syndrome Coronavirus 2 (SARS-CoV-2), in Wuhan City, Hubei Province, China, was first time reported to World Health Organisation (WHO) on 31 December 2019. On 7 January 2020, it was confirmed by Chinese authorities, and on 12 January 2020, WHO confirmed it. The epidemics of Severe Acute Respiratory Syndrome (SARS) and Middle East Acute Respiratory Syndrome (MARS) in the past and the recent outbreaks of infectious diseases like Ebola and H1N1 influenza make us conscientious about comprehending the spread of such viruses and consequences regarding life losses, morbidity, economic burden, and political instability. It is utmost crucial to control the spread and outbreak at the very first case of the disease. It is highly transmittable zoonotic coronavirus disease. The first step for academicians and any government agencies, beforehand, is to study the basic reproduction rate $\left(R_{0}\right)$ which is the average number of secondary infectious cases produced by an infectious case, that provides the plausibility of the spread, outbreak, and severity of an epidemic in a short time available to them. The value of $\mathrm{R}_{0}$ greater than one indicates the number of infectious persons is likely to increase and the value of $\mathrm{R}_{0}$ less than one indicates the transmission is likely to die out. $\mathrm{R}_{0}$ determines the potential for an epidemic spread in a susceptible population in the absence of specific control measures (Koff, 1992; World Health Organization, 2003). For understanding the transmissibility of SARS-CoV-2 in population, every country had made efforts for estimating the $\mathrm{R}_{0}$. Numerous studies have shown that recovery rate has remained more or less the same, but reproduction rate and case fatality rate (CFR) varied across the regions (Fanelli and Piazza 2020, p. 4). The case fatality rate is defined as the percentage of individuals with symptomatic or confirmed diseases who die from the disease. The case fatality rate is currently in the range of 2-8 per cent but has varied across the age groups - higher at old ages and lower at child and adult ages. The estimates of CFR based on hospital records lies in the range of 8-28 per cent (Verity et al. 2020, p. 2). These estimates are evidence to the severity of coronavirus in a short time of its outbreak.

The incubation period of $\mathrm{R}_{0}$ is in the range of 5 to 14 days which may be followed by death in without treatments or in no control measures. The severity of this disease remained suspicious because the onset of the disease is often unknown, and crude CFR is heavily underreported. Therefore, in the absence of control measures and no vaccination, this disease for an infected person is just fatal-the high immunity level to protect a person is an assumption in this case. The effect of MARS and SARS are known in the past; however, the variants of SARS or MARS are acute killer diseases.

The effective reproduction rate $\left(\mathrm{R}_{\mathrm{t}}\right)$, which is the potential for epidemic spread at a time ' $\mathrm{t}$ ' under the control measures, is a function of $\mathrm{R}_{0}$ and proportion of the susceptible population (Cao et al., 2020). Since the incidence of new cases of SARS-CoV-2, the $\mathrm{R}_{0}$ is crucial to understand the mechanism as well as the implementation strategies to reach an effective value of $R_{t}$ which should be less than one for containing the outbreak. The epidemic is considered to be under control when $\mathrm{R}_{t}$ is less than one. The CFR is quite easily measurable and less sensitive to censoring and bias compared to $\mathrm{R}_{0}$. The moments of the distribution of death and mortality patterns are most useful for calculating adjusted CFR; however, $\mathrm{R}_{0}$ is quite sensitive to the onset of diseases and the number of days to get a prediction. In other cases, it is $R_{t}$ which is time-variant and mathematically, a limiting case of $\mathrm{R}_{0}$. Nevertheless, $\mathrm{R}_{0}$ is the most warranted statistics of the epidemiological model for COVID-19.

This study aims to provide, from a systematic review and a meta-analysis, a summary statistic of $\mathrm{R}_{0}$ and CFR which has the best applicability for other regions or countries as well as the lower level of geography districts and towns/village at the point of the onset of disease in a 
medRxiv preprint doi: https://doi.org/10.1101/2020.05.13.20100750; this version posted May 16, 2020. The copyright holder for this preprint (which was not certified by peer review) is the author/funder, who has granted medRxiv a license to display the preprint in perpetuity. It is made available under a CC-BY-ND 4.0 International license .

susceptible population. This summary statistics of $\mathrm{R}_{0}$ and CFR would be of immense utility to government authorities for the practical implementation of strategies or control measures at the very initial phase of the COVID-19 disease transmission.

\section{Objectives}

1) To summarise the characteristics of studies specific to the basic reproduction rate $\left(\mathrm{R}_{0}\right)$ and case fatality rate (CFR) of COVID-19

2) To access and compute the basic reproduction rate and case fatality rate among the confirmed cases of COVID-19

\section{Methods}

We accessed the works of literature from the PubMed MEDLINE database. Based on the terms "coronavirus" in All Fields in PubMed MEDLINE search, the search in the database showed 3536 number of articles. With "COVID-19" in the field Title/Abstract, it showed 2248 number of articles. The preliminary basic search showed significant works of literature that are available to allow work on the systematic review of overall COVID-19.

\section{A systematic review of $\mathbf{R}_{\mathbf{0}}$}

From this broad set of works of literature, we selected research articles with description on reproduction number/rates, based on the terms 'coronavirus reproduction' in All Fields AND "COVID-19" in the field Title/Abstract. It gave an output of 173 number of articles. After applying filters for the English language, Free full text, and between the dates 15/12/2019 and 03/05/2020, it gave an output of 90 number of research articles which are peer-reviewed only for screening, so that we consider the complete works of literature. After reviewing the keywords and abstracts of these articles, we come to know that many of these works of literature have not worked on estimation of the parameters of epidemiological models such as reproduction number/rate, case fatality rate, transmission rate etc. As the focus of this paper is a meta-analysis of reproduction rate and case fatality rate, we extend our search of articles that solved for the estimation of reproduction rate and case fatality rate. We intend to look for articles in which reproduction number/rate or case fatality rate is estimated or calculated using some methods or methodology. Making our search more extensive, for reproduction number/rate, we searched on the basis of terms 'coronavirus reproduction estimation' in All Fields AND 'COVID-19' in the field Title/Abstract. This search in PubMed MEDLINE gives output for 29 articles to explore the parameter estimates of reproduction rates as well as the methodologies and epidemiological models. We reviewed title, keywords, abstracts and data and methods or methods/methodology, and references in these articles. We found three research articles which were based on a descriptive systematic review or general discussion focused on reproduction rates. Another two research articles were based on a systematic review, and only one research article was based on a meta-analysis of $R_{0}$. Out of 29 articles, we found 24 research articles that provided 30 counts of $R_{0}$ values with related statistics for a meta-analysis (Flowchart 1).

\section{A systematic review of CFR}

Similarly, for case fatality rate, considering 2488 numbers of research articles as the starting point of a systematic review, we searched with terms 'coronavirus and mortality' in All Fields AND 'COVID-19' in Title/Abstract that gave an output of 118 research articles, and with terms 'fatality' in All Fields AND 'COVID-19' in the Title/Abstract gave an output of 220 articles, and with terms, 'fatality estimation risk' OR 'fatality estimation model' OR 'coronavirus mortality model parameter' in All Fields AND 'COVID-19' in the Title/Abstract gave an output of 35 articles. Then, we applied the filters of the English language, Free full text, and 
medRxiv preprint doi: https://doi.org/10.1101/2020.05.13.20100750; this version posted May 16, 2020. The copyright holder for this preprint (which was not certified by peer review) is the author/funder, who has granted medRxiv a license to display the preprint in perpetuity. It is made available under a CC-BY-ND 4.0 International license .

between the dates 15/12/2019 and 03/05/2020, which gave an output of 24 articles. We reviewed these research articles searching for titles, abstract and keywords, methodology and references. Out of these 24 articles, only 17 qualified for quantifying parameter values of CFR (Flowchart 2). These 17 articles provided 29 counts of CFR for a meta-analysis.

Flowchart 1: Flow diagram for the selected research articles for $\mathbf{R}_{\mathbf{0}}$
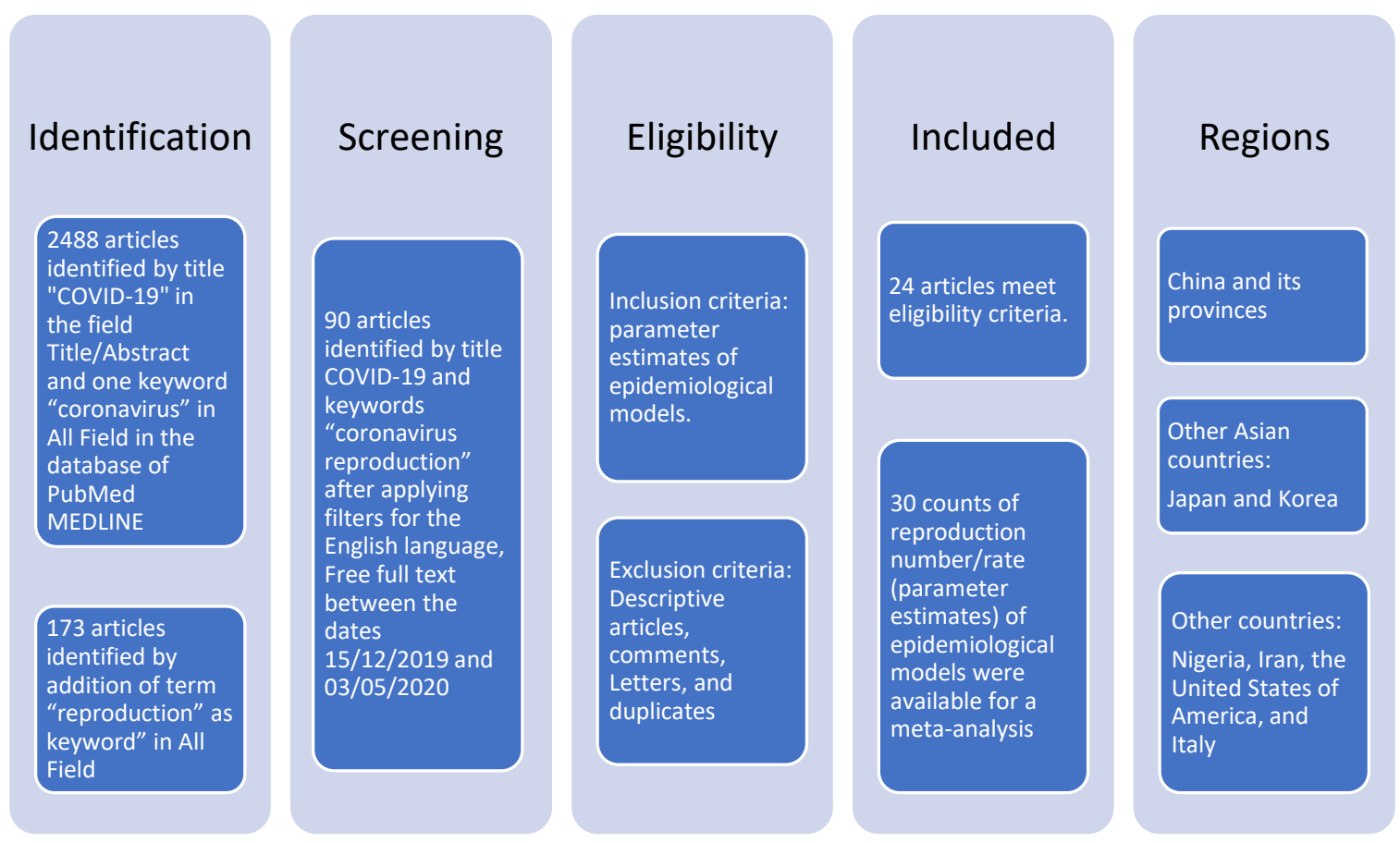
medRxiv preprint doi: https://doi.org/10.1101/2020.05.13.20100750; this version posted May 16, 2020. The copyright holder for this preprint (which was not certified by peer review) is the author/funder, who has granted medRxiv a license to display the preprint in perpetuity. It is made available under a CC-BY-ND 4.0 International license .

Flowchart 2: Flow diagram for the selected research articles for CFR
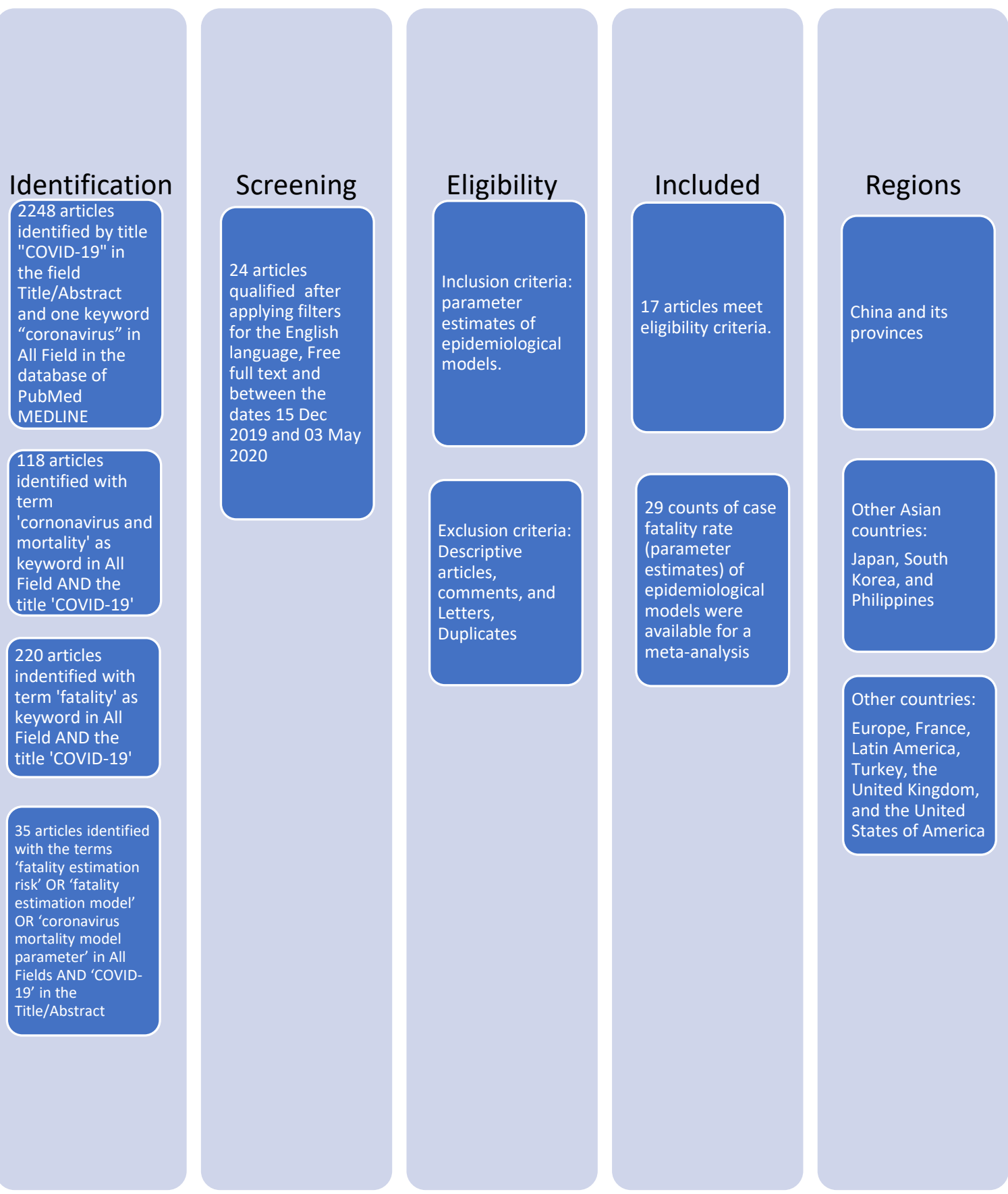

\section{Reproduction number/rate $\left(R_{0}\right)$ and Case fatality rate: parameter values of an epidemiological model}

The review of methodologies of these 24 peer-reviewed articles for $\mathrm{R}_{0}$ and 17 peer-reviewed articles for CFR revealed that the studies lacked the control groups. The $\mathrm{R}_{0}$ and CFR values were retrieved from these published articles after careful reading and analysing the sections of 'Data and Methods' or 'Methods' or 'Methodology' and the 'Results with tables and figures.' This allowed to extract the date of publication, the period of study, application of methods, confirmed cases, susceptible cases, the $\mathrm{R}_{0}$ values, the CFR values, and relevant statistics such as confidence interval, standard error, sample size etc. For every statistic collected, we checked for any references mentioned against the source of statistic to avoid the duplication of estimates 
medRxiv preprint doi: https://doi.org/10.1101/2020.05.13.20100750; this version posted May 16, 2020. The copyright holder for this preprint (which was not certified by peer review) is the author/funder, who has granted medRxiv a license to display the preprint in perpetuity. It is made available under a CC-BY-ND 4.0 International license.

in two or more pieces of literature quoted from the same source of the work of literature. In this manner, the statistics of $\mathrm{R}_{0}$ and CFR computed in these studies qualified for a metaanalysis. The extracted $\mathrm{R}_{0}$ values were furthermore examined by the period of study. Many studies have given an effective reproduction rate $\left(\mathrm{R}_{\mathrm{t}}\right)$ along with $\mathrm{R}_{0}$ values; nevertheless, we consider the initial period of analysis and $\mathrm{R}_{0}$ values from the first phase of evolving epidemiology of the disease. A few of the studies have given several $\mathrm{R}_{0}$ values starting from the onset of the diseases until the end of the study. In such cases, we included the $\mathrm{R}_{0}$ values of the very onset period of the disease. The initial period or the first phase in these studies ranged between $\sim 5$ days to $\sim 12$ days. Analysing CFR, we included only adjusted case fatality rate standardised for age and sex distributions or for censored cases. Crude case fatality rates were excluded for a meta-analysis. Although several values of CFR were shown in a study, we included only those estimates based on deaths that comprise the sample of an epidemiological model. Two or more estimates of $\mathrm{R}_{0}$ and CFR were considered from the same study if it belonged to different regions or periods or were estimated from different method(s).

\section{Data extraction}

We extracted the following variables: author, publication date, year, co-authors, sample size, mean statistics of $\mathrm{R}_{0}$, confidence interval, methods applied, standard deviation, and any other relevant statistics. All the studies, 24 for $\mathrm{R}_{0}$ and 17 for CFR were retained in the present study. These selected studies provided 30 counts of $R_{0}$ and 29 counts of CFR for a meta-analysis. Table 1 and Table 2 show respectively for $\mathrm{R}_{0}$ and CFR, from the list of works of literature, the estimates of published $\mathrm{R}_{0}$ and CFR by authors applying different methodologies.

\section{Analyses}

We performed the meta-analysis to estimate the mean effect size and its precision. The metaanalysis can be performed using the inverse variance method, fixed-effects model, and randomeffects model. The Higgin's \& Thompson's $I^{2}$ statistic, Tau-squared $\left(\tau^{2}\right)$, and Cochran's Q test were applied to test statistical heterogeneity among the selected studies. The test of heterogeneity was applied for understanding the application of the random-effects model versus the fixed-effects model in a meta-analysis. We plotted Forest plot using the randomeffects model with prediction values of $95 \%$ confidence intervals. We plotted Funnel plot at $95 \%, 97.5 \%$, and $99 \%$ confidence intervals to testify the publication bias in this meta-analysis of COVID-19.

\section{Results}

\section{A meta-analysis of published $R_{0}$ and CFR values}

The average $\mathrm{R}_{0}$ value and CFR value was computed at a value of 3.72 (3.43-4.04) persons (Table 1) and 3.96 (3.67- 4.27) per cent (Table 2), respectively, based on inverse variance method. We performed a test of heterogeneity to check whether these works of literature stem from the same population or from a universe of a population. The applied test of heterogeneity is shown in Table 3. The Higgin's \& Thompson's $I^{2}$ statistic, which is the percentage of variability in the effect sizes not caused by sampling errors, greater than 75 per cent indicates a presence of high heterogeneity among these works of literature. The high value of $99.9 \% I^{2}$ statistic confirms that these studies did not stem from the same population. The other two statistics which are tau-squared $\left(\tau^{2}\right)$ statistic, the between-study variance in a meta-analysis, and Cochran's Q-statistic, the difference between the observed effect sizes and fixed-effects model, are significant for $\mathrm{R}_{0}$ as well as for CFR (Table 3). These tests of heterogeneity were quite important for deciding the application of fixed-effects or random-effects models for a meta-analysis. The fixed-effects model assumes that the studies stem from the same population 
medRxiv preprint doi: https://doi.org/10.1101/2020.05.13.20100750; this version posted May 16, 2020. The copyright holder for this preprint

(which was not certified by peer review) is the author/funder, who has granted medRxiv a license to display the preprint in perpetuity. It is made available under a CC-BY-ND 4.0 International license .

whereas the random-effects model is based on the fact the studies stem from the universe of population. Results from the test of heterogeneity suggest for applying the random-effects model rather than for applying the fixed-effects model for a meta-analysis. We computed the mean $\mathrm{R}_{0}$ value and mean CFR value (mean effect sizes) were computed, using the randomeffects model in a meta-analysis.

The estimates of $\mathrm{R}_{0}$ and CFR were computed using the random-effects model based on data shown in Table 1 and Table 2. We have summarised the estimates of $R_{0}$ in Table 4 and CFR in Table 5 from meta-analysis, using on all data and excluding outliers. We estimated mean value of $\mathrm{R}_{0}$ and CFR, after excluding outliers, at 3.11 (2.49-3.71) persons (Table 4: column (f)) and 2.63 (2.18-3.08) per cent (Table 5: column (f)), respectively, based on the pieces of evidence available across the countries. These estimates are accounted for heterogeneity among the studies and lies within a narrow confidence interval. Hence, these estimates qualify as a high precision estimate. The estimated $\mathrm{R}_{0}$ value based on the random-effects model is slightly lower than that of based on the inverse variance method.

Furthermore, for examining a regional variation, the meta-analysis was performed by subgroups of countries. A minimum sample of three studies is required for performing a subgroup analysis in a meta-analysis. The regional subgroups identified for meta-analysis of $\mathrm{R}_{0}$ are 'China and its provinces', 'other Asian countries' that includes studies based on data from Japan and Korea, and 'other countries' that includes studies based on data from Nigeria, Iran, Italy, and the United States of America (USA). Figure 1 and Figure 2 show Forest plot showing mean effect sizes by regional subgroups for $\mathrm{R}_{0}$ and CFR, respectively, along with the overall effect size, based on the random-effects model. The mean $\mathrm{R}_{0}$ values for the regional subgroup 'China and its provinces' was 3.21 (2.73-3.68) persons, and for 'other Asian countries' was $1.90(1.06-2.74)$ persons and for 'other countries' was 3.83 (2.44-5.22) persons (Table 6). The test of regional subgroup differences using random-effects model is significant with a p-value of 0.013 . This confirms that the estimated mean $\mathrm{R}_{0}$ values are significantly different across these regions. The results revealed that, among these regions, it is the highest for the subgroup 'other countries', wherein it is the highest for the USA. The regional subgroups identified for CFR meta-analysis are 'China and its provinces', 'other Asian countries' that includes study based on data from Japan, South Korea, and the Philippines, and 'other countries' that includes studies based on data from Europe, France, Latin America, Turkey, the United Kingdom (UK), and the USA. The mean CFR values for 'China and its provinces' was 2.53 (1.91-3.14) per cent, for 'other Asian countries' was 2.56 (-0.26-5.38) per cent, and for 'other countries' was 2.78 (2.08-3.47) per cent (Table 7). The test for regional subgroup differences using the random-effects model was not significant $(\mathrm{p}=0.865)$. Hence, it implies that the CFR did not vary significantly across these regions despite the fact that the CFR was the highest in the USA and the lowest in South Korea.

We have also looked at publication bias to test the significance of these studies for a metaanalysis. The Funnel plot for $\mathrm{R}_{0}$ values computed from the random-effects model is shown in Figure 3. This Funnel plot clearly shows that the selected studies of $\mathrm{R}_{0}$ for this meta-analysis are significant at one per cent level of significance, with the exception of two studies which are Muniz-Rodriguez et al. 2020 with the method of doubling time and Kucharski et al. 2020. Similarly, the Funnel plot of CFR is shown in Figure 4, based on the random-effects model. It clearly shows that all studies are significant at one per cent level of significance. The results from the Funnel confirm that even the small sample size studies have also been published in addition to moderate sample size studies and large sample sized studies which are generally project-based. 
medRxiv preprint doi: https://doi.org/10.1101/2020.05.13.20100750; this version posted May 16, 2020. The copyright holder for this preprint

(which was not certified by peer review) is the author/funder, who has granted medRxiv a license to display the preprint in perpetuity. It is made available under a CC-BY-ND 4.0 International license.

\section{Discussion}

This study aims to provide a summary statistic of the basic reproduction rate $\left(\mathrm{R}_{0}\right)$ and the case fatality rate (CFR) for a generalised population based on peer-reviewed published estimates of $\mathrm{R}_{0}$ and CFR from epidemiological models applied on a susceptible population. After an electronic search for such conditions between the dates 15 December 2019 and 3 May 2020 and applying various inclusion and exclusion criteria, this study came across 24 and 17 works of literature for $\mathrm{R}_{0}$ and CFR, respectively that qualified for a meta-analysis. These studies provided 30 counts of $R_{0}$ and 29 counts of CFR for a meta-analysis. The study examined the characteristics of studies and computed the overall effect size or mean $\mathrm{R}_{0}$ and $\mathrm{CFR}$ value. We applied the test of heterogeneity which are Higgin's \& Thompson's $I^{2}$ statistic, tau-squared $\left(\tau^{2}\right)$ statistic, and Cochran's Q-statistic. These test of heterogeneity reveals a high heterogeneity across the studies. The studies included in the meta-analysis had the sources of errors not only from sampling errors but also from the distributions of individual mean effect size. The $\mathrm{R}_{0}$ and CFR values extracted from different studies had their own distributions that were different from an overarching distribution. Therefore, the random-effects model was most appropriate for computing mean $\mathrm{R}_{0}$ value and mean CFR value based on a meta-analysis. After excluding outliers, the estimate of $\mathrm{R}_{0}$ and CFR from these studies was calculated at 3.11 (2.49-3.71) persons (Table 4: column (f)) and 2.63 (2.18-3.08) per cent (Table 5: column (f)), respectively, based on the random-effects model. For $\mathrm{R}_{0}$, the variation by subgroups of regions was significant. It reveals that the $\mathrm{R}_{0}$ values were significantly different across these regional subgroups. However, the regional subgroups differences for CFR was not a significant one. Hence, we conclude that the CFR did not vary across the regions.

Acknowledging the severity of this disease, the estimated $\mathrm{R}_{0}$ value of 3.11 persons and in a narrow confidence interval is a higher and riskier statistic applicable for any generalised population. This $\mathrm{R}_{0}$ statistic implies that one infectious person is transmitting to three other susceptible persons in the absence of any control measures. The $\mathrm{R}_{0}$ value is overall effect size based on various heterogeneous studies. Therefore, this $\mathrm{R}_{0}$ value is most reasonable and sensible for a country or a region encountering the emergence of COVID-19 during the first phase or in the very initial stage of this infectious disease. The meta-analysis by regional subgroups reveals the variation in $\mathrm{R}_{0}$ across the regions (Table 6). Therefore, this study suggests that $\mathrm{R}_{0}$ values based on a meta-analysis from the pieces of evidence across the regions would range between 1.90 (1.06-2.73) person and 3.83 (2.33-5.21) persons. The CFR statistic is based on the period of approximately one-and-a-half months, but it translates to toll deaths in a short span of time. The results of regional subgroup analysis in meta-analysis confirm that the CFR did not vary across the regions. The estimated CFR value of 2.63 per cent (Table 7) without much variation is applicable to any generalised population. For a developing country like India and the second most populated country in the world, the CFR value of 2.63 is most dreadful. Necessary precautions and strategies are utmost important as early as possible to prevent the outbreak of this disease.

\section{Conclusion}

This paper suggests a robust estimate of $\mathrm{R}_{0}$ which is 3.11 (2.49-3.71) persons in the absence of any control measures and a robust estimate of CFR equals to 2.63 (2.18-3.08) per cent for a generalised population in a period of one-and-a-half months from the onset of disease COVID19. The analysis by subgroups of regions using the Forest plot confirms a significant variation for $\mathrm{R}_{0}$, but the same is not found significant for CFR. The $\mathrm{R}_{0}$ values would most probably be in the range of $1.90(1.06-2.73)$ person and 3.83 (2.33-5.21) persons for a region. The Funnel plot confirms that the included studies were significant, and therefore, it establishes the robustness of $\mathrm{R}_{0}$ and CFR based on the data of these studies in a meta-analysis. We proclaim 
medRxiv preprint doi: https://doi.org/10.1101/2020.05.13.20100750; this version posted May 16, 2020. The copyright holder for this preprint (which was not certified by peer review) is the author/funder, who has granted medRxiv a license to display the preprint in perpetuity. It is made available under a CC-BY-ND 4.0 International license.

that one person is likely to infect three persons in the absence of any control measures and the around three per cent of the population are at the risk of death in a period of one-and-a-half months from the onset of disease COVID-19 in a generalised population.

The estimates of $\mathrm{R}_{0}$ and CFR are unequivocally applicable to any generalised population at the point of emergence of the disease COVID-19. Hence these estimates are worthwhile for a region/country and its lower geography. These robust estimates are applicable for developing country India and its states or districts.

\section{Limitation of the study}

This study is based on a meta-analysis of recently published articles that estimated for parameters of epidemiological models for COVID-19. The period for analysis for COVID-19 is more than three months from 15 December 2019 to 3 May 2020. We retrieved studies which are peer-reviewed research papers and are mostly from the regions which have encountered the epidemic in an area or pandemic in a country or nation at the very early emergence of SARSCoV-2. Many of these peer-reviewed studies have used data mainly from China and its provinces. Some of these studies had analysed data from other Asian countries and a few from other parts of the world. Therefore, a wide and rich regional view of data was not available in the period of study. Most of these studies in itself have the disadvantage of small sample size and missing information on the time of onset of SARS-CoV-2. Accordingly, the authors of these selected published papers have used generalised epidemiological models to get robust estimates. Most of these have used time-varying models using simulation methods and the moments of statistical distributions for estimating parameters of the epidemiological models. We also, in order to overcome such limitations of small sample size, have estimated the mean $\mathrm{R}_{0}$ and CFR values using the random-effects model which make the estimation of parameter based on the assumption that these studies stem from a universe of population. Therefore, the estimates of $\mathrm{R}_{0}$ and CFR in this study is robust and applicable to a generalised population. In addition to that, nonetheless, the Funnel plot for both $\mathrm{R}_{0}$ and CFR showed that these publications are important to consider for a meta-analysis, as these studies are found statistically significant for examining COVID-19.

\section{Acknowledgments}

Authors would like to thank Prof. K.S. James, Director and Senior Professor, International

Institute for Population Sciences (IIPS), Mumbai, for his recommendations and suggestions to carry out this study and for providing constructive comments which helped greatly in improving the quality of the policy brief. IIPS team of researchers on Estimation and Projection of COVID 19 Cases would also like to thank him for initiating policy briefs on COVID-19.

\section{IIPS team of researchers on Estimation and Projection of COVID 19 Cases:}

Dr. Sayeed Unisa, Professor and Head, Department of Mathematical Demography and Statistics International Institute for Population Sciences, Mumbai. (email id: unisa@iips.net)

Dr. Chander Shekhar, Professor, Department of Fertility Studies, International Institute for Population Sciences, Mumbai. (email id:buddhab@iips.net)

Dr. Usha Ram, Professor, Department of Department of Public Health \& Mortality Studies International Institute for Population Sciences, Mumbai. (email id:usharam@iips.net) 
medRxiv preprint doi: https://doi.org/10.1101/2020.05.13.20100750; this version posted May 16, 2020. The copyright holder for this preprint (which was not certified by peer review) is the author/funder, who has granted medRxiv a license to display the preprint in perpetuity. It is made available under a CC-BY-ND 4.0 International license .

Dr. Laxmi Kant Dwivedi, Assistant Professor, Department of Mathematical Demography and Statistics, International Institute for Population Sciences, Mumbai. (email id:laxmikant@iips.net)

Dr. Suryakant Yadav, Assistant Professor, Department of Development Studies, International Institute for Population Sciences, Mumbai. (email id: suryakant_yadav@iips.net; suryakant11@gmail.com)

Dr. Preeti Dhillon, Assistant Professor, Department of Mathematical Demography and Statistics, International Institute for Population Sciences, Mumbai. (email id:pdhillon@iips.net)

Mr. Pawan Kumar Yadav, Research Scholar, Mumbai, India (Email: pawankumaryadavbhu@gmail.com)

M. Kishore, M.Phil. Research Scholar, International Institute for Population Sciences, Mumbai. (email id: kishorem896@ gmail.com)

\section{References}

Adegboye, O. A., Adekunle, A. I., \& Gayawan, E. (2020). Early Transmission Dynamics of Novel Coronavirus (COVID-19) in Nigeria. International Journal of Environmental Research and Public Health, 17(9), 3054.

Amariles, P., Granados, J., Ceballos, M., \& Montoya, C. J. (2020). COVID-19 in Colombia endpoints. Are we different, like Europe?. Research in Social and Administrative Pharmacy.

Anastassopoulou, C., Russo, L., Tsakris, A., \& Siettos, C. (2020). Data-based analysis, modelling and forecasting of the COVID-19 outbreak. PloS one, 15(3), e0230405.

Bayham, J., \& Fenichel, E. P. (2020). Impact of school closures for COVID-19 on the US health-care workforce and net mortality: a modelling study. The Lancet Public Health.

Boldog, P., Tekeli, T., Vizi, Z., Dénes, A., Bartha, F. A., \& Röst, G. (2020). Risk assessment of novel coronavirus COVID-19 outbreaks outside China. Journal of clinical medicine, 9(2), 571.

Choi, S., \& Ki, M. (2020). Estimating the reproductive number and the outbreak size of Novel Coronavirus disease (COVID-19) using mathematical model in Republic of Korea. Epidemiology and Health, e2020011.

Chatterjee, P., Nagi, N., Agarwal, A., Das, B., Banerjee, S., Sarkar, S., ... \& Gangakhedkar, R. R. (2020). The 2019 novel coronavirus disease (COVID-19) pandemic: A review of the current evidence. Indian Journal of Medical Research, 151(2), 147.

Fanelli, Duccio and Piazza, Francesco (2020). Analysis and forecast of COVID-19 spreading in China, Italy, and France. Chaos, Solitons, \& Fractals, Vol. 134. DOI: https://doi.org/10.1016/j.chaos.2020.109761.

Fu, L., Wang, B., Yuan, T., Chen, X., Ao, Y., Fitzpatrick, T., ... \& Luo, G. (2020). Clinical characteristics of coronavirus disease 2019 (COVID-19) in China: a systematic review and meta-analysis. Journal of Infection.

Geldsetzer, P. (2020). Use of Rapid Online Surveys to Assess People's Perceptions During Infectious Disease Outbreaks: A Cross-sectional Survey on COVID-19. Journal of medical Internet research, 22(4), e18790. 
medRxiv preprint doi: https://doi.org/10.1101/2020.05.13.20100750; this version posted May 16, 2020. The copyright holder for this preprint (which was not certified by peer review) is the author/funder, who has granted medRxiv a license to display the preprint in perpetuity. It is made available under a CC-BY-ND 4.0 International license.

Jung, S. M., Akhmetzhanov, A. R., Hayashi, K., Linton, N. M., Yang, Y., Yuan, B., ... \& Nishiura, H. (2020). Real-time estimation of the risk of death from novel coronavirus (COVID-19) infection: inference using exported cases. Journal of clinical medicine, 9(2), 523.

Kobayashi, T., Jung, S. M., Linton, N. M., Kinoshita, R., Hayashi, K., Miyama, T., ... \& Suzuki, A. (2020). Communicating the risk of death from novel coronavirus disease (COVID19).

Koff RS, World Health Organization (1992) Wu JT, et al. Infectious diseases of humans: Dynamics and control. By R.M. Anderson and R.M. May, 757 pp. Oxford: Oxford University Press, 1991. \$95.00. Hepatology. 2020. doi:10.1101/2020.01.27.20018952.

Kucharski, A. J., Russell, T. W., Diamond, C., Liu, Y., Edmunds, J., Funk, S., ... \& Davies, N. (2020). Early dynamics of transmission and control of COVID-19: a mathematical modelling study. The lancet infectious diseases.

Kuniya, T. (2020). Prediction of the epidemic peak of Coronavirus Disease in Japan, 2020. Journal of Clinical Medicine, 9(3), 789.

Lai, C. C., Shih, T. P., Ko, W. C., Tang, H. J., \& Hsueh, P. R. (2020). Severe acute respiratory syndrome coronavirus 2 (SARS-CoV-2) and corona virus disease-2019 (COVID-19): the epidemic and the challenges. International journal of antimicrobial agents, 105924.

Medina, M. A. (2020). Preliminary Estimate of COVID-19 Case Fatality Rate in the Philippines using Linear Regression Analysis. Available at SSRN 3569248.

Mizumoto, K., \& Chowell, G. (2020). Estimating risk for death from 2019 novel coronavirus disease, China, January-February 2020. Emerg Infect Dis, 26(6), 10-3201.

Muniz-Rodriguez, K., Fung, I. C., Ferdosi, S. R., Ofori, S. K., Lee, Y., Tariq, A., \& Chowell, G. (2020). Severe Acute Respiratory Syndrome Coronavirus 2 Transmission Potential, Iran, 2020. Emerging Infectious Diseases, 26(8).

Öztoprak, F., \& Javed, A. Case Fatality Rate estimation of COVID-19 for European Countries: Turkey's Current Scenario Amidst a Global Pandemic; Comparison of Outbreaks with European Countries. world, 21, 24.

Peirlinck, M., Costabal, F. S., Linka, K., \& Kuhl, E. (2020). Outbreak dynamics of COVID-19 in China and the United States. medRxiv.

Riou, J., \& Althaus, C. L. (2020). Pattern of early human-to-human transmission of Wuhan 2019 novel coronavirus (2019-nCoV), December 2019 to January 2020. Eurosurveillance, 25(4), 2000058.

Russo, L., Anastassopoulou, C., Tsakris, A., Bifulco, G. N., Campana, E. F., Toraldo, G., \& Siettos, C. (2020). Tracing DAY-ZERO and Forecasting the Fade out of the COVID19 Outbreak in Lombardy, Italy: A Compartmental Modelling and Numerical Optimization Approach. medRxiv.

Rocklöv, J., Sjödin, H., \& Wilder-Smith, A. (2020). COVID-19 outbreak on the Diamond Princess cruise ship: estimating the epidemic potential and effectiveness of public health countermeasures. Journal of travel medicine.

Russell, T. W., Hellewell, J., Jarvis, C. I., Van Zandvoort, K., Abbott, S., Ratnayake, R., ... \& CMMID COVID-19 working group. (2020). Estimating the infection and case fatality ratio for coronavirus disease (COVID-19) using age-adjusted data from the outbreak 
medRxiv preprint doi: https://doi.org/10.1101/2020.05.13.20100750; this version posted May 16, 2020. The copyright holder for this preprint (which was not certified by peer review) is the author/funder, who has granted medRxiv a license to display the preprint in perpetuity. It is made available under a CC-BY-ND 4.0 International license.

on the Diamond Princess cruise ship, February 2020. Eurosurveillance, 25(12), 2000256.

Sanche, S., Lin, Y. T., Xu, C., Romero-Severson, E., Hengartner, N., \& Ke, R. (2020). High Contagiousness and Rapid Spread of Severe Acute Respiratory Syndrome Coronavirus 2. Emerging infectious diseases, 26(7).

Shim, E., Tariq, A., Choi, W., Lee, Y., \& Chowell, G. (2020). Transmission potential and severity of COVID-19 in South Korea. International Journal of Infectious Diseases.

Tang, B., Xia, F., Tang, S., Bragazzi, N. L., Li, Q., Sun, X., ... \& Wu, J. (2020). The effectiveness of quarantine and isolation determine the trend of the COVID-19 epidemics in the final phase of the current outbreak in China. International Journal of Infectious Diseases.

Tsang, J., \& Bajpai, J. (2020). Novel Coronavirus Infection-Knowns and Unknowns with Particular Reference to Oncology-Combating against COVID-19 with "COVID". Indian J Med Paediatr Oncol.

Verity, R., Okell, L. C., Dorigatti, I., Winskill, P., Whittaker, C., Imai, N., ... \& Dighe, A. (2020). Estimates of the severity of coronavirus disease 2019: a model-based analysis. The Lancet Infectious Diseases.

Wang, Y., You, X. Y., Wang, Y. J., Peng, L. P., Du, Z. C., Gilmour, S., ... \& Li, J. H. (2020). Estimating the basic reproduction number of COVID-19 in Wuhan, China. Zhonghua liu Xing Bing xue za zhi= Zhonghua Liuxingbingxue Zazhi, 41(4), 476-479.

Wang, Z., \& Liu, M. (2020). Estimating COVID-19 Case Fatality Rate in the Middle of the Outbreak: Deadlier than Previously Estimated. Available at SSRN 3555242.

Wilson, N., Kvalsvig, A., Barnard, L. T., \& Baker, M. G. (2020). Case-Fatality Risk Estimates for COVID-19 Calculated by Using a Lag Time for Fatality. Emerging infectious diseases, 26(6).

World Health Organization (2003) Consensus Document on the Epidemiology of Severe Acute Respiratory Syndrome (SARS). Working paper, WHO.

Yang, S., Cao, P., Du, P., Wu, Z., Zhuang, Z., Yang, L., ... \& Li, W. (2020). Early estimation of the case fatality rate of COVID-19 in mainland China: a data-driven analysis. Annals of Translational Medicine, 8(4).

Zhao, S., Lin, Q., Ran, J., Musa, S. S., Yang, G., Wang, W., ... \& Wang, M. H. (2020). Preliminary estimation of the basic reproduction number of novel coronavirus (2019$\mathrm{nCoV}$ ) in China, from 2019 to 2020: A data-driven analysis in the early phase of the outbreak. International journal of infectious diseases, 92, 214-217.

Zhao, S., Musa, S. S., Lin, Q., Ran, J., Yang, G., Wang, W., ... \& Wang, M. H. (2020). Estimating the unreported number of novel coronavirus (2019-nCoV) cases in China in the first half of January 2020: a data-driven modelling analysis of the early outbreak. Journal of clinical medicine, 9(2), 388.

Zhuang, Z., Zhao, S., Lin, Q., Cao, P., Lou, Y., Yang, L., ... \& Xiao, L. (2020). Preliminary estimating the reproduction number of the coronavirus disease (COVID-19) outbreak in Republic of Korea and Italy by 5 March 2020. International Journal of Infectious Diseases.

Zhang, S., Diao, M., Yu, W., Pei, L., Lin, Z., \& Chen, D. (2020). Estimation of the reproductive number of novel coronavirus (COVID-19) and the probable outbreak size on the 
medRxiv preprint doi: https://doi.org/10.1101/2020.05.13.20100750; this version posted May 16, 2020. The copyright holder for this preprint (which was not certified by peer review) is the author/funder, who has granted medRxiv a license to display the preprint in perpetuity. It is made available under a CC-BY-ND 4.0 International license.

Diamond Princess cruise ship: A data-driven analysis. International Journal of Infectious Diseases, 93, 201-204.

Zhou, W., Wang, A., Xia, F., Xiao, Y., \& Tang, S. (2020). Effects of media reporting on mitigating spread of COVID-19 in the early phase of the outbreak.

Zhu, Y., \& Chen, Y. Q. (2020). On a Statistical Transmission Model in Analysis of the Early Phase of COVID-19 Outbreak. Statistics in Biosciences, 1.

\section{Tables}

Table 1: Characteristics of included studies in the meta-analysis of $R_{0}$

\begin{tabular}{|c|c|c|c|c|c|}
\hline $\begin{array}{l}\text { Author/ } \\
\text { Study }\end{array}$ & $\begin{array}{c}\text { Region/ } \\
\text { Time period } \\
\text { (Date/Month/Y } \\
\text { ear) }\end{array}$ & Methodology & $\begin{array}{c}\text { Basic } \\
\text { Reproduct } \\
\text { ion } \\
\text { Number/r } \\
\text { ate }\left(\mathbf{R}_{0}\right)\end{array}$ & $\begin{array}{c}95 \% \\
\text { Confidence } \\
\text { Interval } \\
\text { (CI) }\end{array}$ & $\begin{array}{l}\text { Confirmed } \\
\text { (C) and } \\
\text { Susceptible } \\
\text { (S) cases }\end{array}$ \\
\hline $\begin{array}{l}\text { Adegboye } \\
\text { et al. } 2020\end{array}$ & $\begin{array}{l}\text { Nigeria } \\
\text { 27/02/2020- } \\
19 / 03 / 2020\end{array}$ & $\begin{array}{l}\text { Bayesian method } \\
\text { (Short duration) }\end{array}$ & 4.98 & $2.65-8.41$ & $318(\mathrm{C})$ \\
\hline $\begin{array}{l}\text { Adegboye } \\
\text { et al. } 2020\end{array}$ & $\begin{array}{l}\text { Nigeria } \\
27 / 02 / 2020- \\
11 / 04 / 2020\end{array}$ & $\begin{array}{l}\text { Bayesian method } \\
\text { (Long duration) }\end{array}$ & 1.42 & $1.26-1.58$ & $318(\mathrm{C})$ \\
\hline $\begin{array}{l}\text { Anastasso } \\
\text { poulou et } \\
\text { al. } 2020\end{array}$ & $\begin{array}{l}\text { Hubei Province } \\
\text { (China) } \\
11 / 01 / 2020- \\
20 / 01 / 2020\end{array}$ & $\begin{array}{l}\text { Susceptible, } \\
\text { Infected, } \\
\text { Recovered and } \\
\text { Dead (SIRD) } \\
\text { models } \\
\text { (Long duration) }\end{array}$ & 7.09 & $5.84-8.35$ & $\begin{array}{r}59000000 \\
(\mathrm{~S})\end{array}$ \\
\hline $\begin{array}{l}\text { Anastasso } \\
\text { poulou et } \\
\text { al. } 2020\end{array}$ & $\begin{array}{l}\text { Hubei Province } \\
\text { (China) } \\
11 / 01 / 2020- \\
16 / 01 / 2020\end{array}$ & $\begin{array}{l}\text { Susceptible, } \\
\text { Infected, } \\
\text { Recovered and } \\
\text { Dead (SIRD) } \\
\text { models } \\
\text { (Short duration) }\end{array}$ & 4.8 & $3.36-6.67$ & $\begin{array}{r}59000000 \\
(\mathrm{~S})\end{array}$ \\
\hline
\end{tabular}


medRxiv preprint doi: https://doi.org/10.1101/2020.05.13.20100750; this version posted May 16, 2020. The copyright holder for this preprint (which was not certified by peer review) is the author/funder, who has granted medRxiv a license to display the preprint in perpetuity. It is made available under a CC-BY-ND 4.0 International license.

\begin{tabular}{|c|c|c|c|c|c|}
\hline $\begin{array}{l}\text { Boldog et } \\
\text { al. } 2020\end{array}$ & $\begin{array}{l}\text { Hubei Province } \\
\text { (China) } \\
23 / 01 / 2020- \\
31 / 01 / 2020\end{array}$ & $\begin{array}{l}\text { Time-dependent } \\
\text { compartmental } \\
\text { model, Galton- } \\
\text { Watson } \\
\text { branching } \\
\text { process }\end{array}$ & 2.6 & $2.1-3.1$ & - \\
\hline $\begin{array}{l}\text { Choi and } \\
\text { Ki } 2020\end{array}$ & $\begin{array}{l}\text { Hubei Province } \\
\text { (China) } \\
20 / 01 / 2020- \\
17 / 02 / 2020\end{array}$ & $\begin{array}{l}\text { Susceptible }(\mathrm{S}), \\
\text { Exposed } \\
\text { Symptomatic } \\
\text { Infectious } \\
\text { hospitalised }(\mathrm{I}) \\
\text { recovered } \\
\text { death or } \\
\text { SEIHR model }\end{array}$ & 4.028 & 4.01-4.046 & $4992000(\mathrm{~S})$ \\
\hline $\begin{array}{l}\text { Choi and } \\
\text { Ki } 2020\end{array}$ & $\begin{array}{l}\text { Korea } \\
\text { 18/02/2020- } \\
\text { 24/02/2020 }\end{array}$ & $\begin{array}{l}\text { Susceptible }(\mathrm{S}), \\
\text { Exposed }(\mathrm{E}), \\
\text { Symptomatic } \\
\text { infectious }(\mathrm{I}) \\
\text { hospitalised }(\mathrm{H}) \\
\text { recovered or } \\
\text { death } \quad(\mathrm{R}) \text { : } \\
\text { SEIHR model }\end{array}$ & 0.555 & $0.51-0.60$ & $30(\mathrm{C})$ \\
\hline $\begin{array}{l}\text { Jung et al. } \\
2020\end{array}$ & $\begin{array}{l}\text { China } \\
\text { 08/12/2019- } \\
\text { 24/01/2020 }\end{array}$ & $\begin{array}{l}\text { Delay } \\
\text { distributions, } \\
\text { Markov Chain } \\
\text { Monte } \quad \text { Carlo } \\
\text { (MCMC) }\end{array}$ & 3.2 & $2.7-3.7$ & $20(\mathrm{C})$ \\
\hline $\begin{array}{l}\text { Kucharski } \\
\text { et. al. } \\
2020\end{array}$ & $\begin{array}{l}\text { Wuhan (China) } \\
\text { 29/12/2019- } \\
\text { 23/01/2020 }\end{array}$ & $\begin{array}{l}\text { Stochastic } \\
\text { transmission } \\
\text { dynamic model, } \\
\text { Geometric } \\
\text { random walk, } \\
\text { Markov Chain } \\
\text { Monte Carlo } \\
(\text { MCMC) }\end{array}$ & 2.35 & $1.15-4.77$ & - \\
\hline $\begin{array}{l}\text { Kuniya } \\
2020\end{array}$ & $\begin{array}{l}\text { Japan } \\
\text { 15/01/2020- } \\
29 / 02 / 2020\end{array}$ & $\begin{array}{l}\text { SEIR } \\
\text { compartmental } \\
\text { model }\end{array}$ & 2.6 & $2.4-2.8$ & $239(\mathrm{C})$ \\
\hline $\begin{array}{l}\text { Lai et al. } \\
2020\end{array}$ & $\begin{array}{l}\text { mainland China } \\
\text { 31/12/2019- } \\
\text { 28/01/2020 }\end{array}$ & $\begin{array}{l}\text { Pooling of } \\
\text { estimates from } \\
\text { different studies }\end{array}$ & 2.68 & $2.47-2.86$ & $278(\mathrm{C})$ \\
\hline
\end{tabular}


medRxiv preprint doi: https://doi.org/10.1101/2020.05.13.20100750; this version posted May 16, 2020. The copyright holder for this preprint (which was not certified by peer review) is the author/funder, who has granted medRxiv a license to display the preprint in perpetuity. It is made available under a CC-BY-ND 4.0 International license.

\begin{tabular}{|c|c|c|c|c|c|}
\hline $\begin{array}{l}\text { Muniz- } \\
\text { Rodriguez } \\
\text { et al. } 2020\end{array}$ & $\begin{array}{l}\text { Iran } \\
\text { 19/02/2020- } \\
19 / 03 / 2020\end{array}$ & $\begin{array}{l}\text { Generalised } \\
\text { growth model }\end{array}$ & 4.4 & $3.9-4.9$ & - \\
\hline $\begin{array}{l}\text { Muniz- } \\
\text { Rodriguez } \\
\text { et al. } 2020\end{array}$ & $\begin{array}{l}\text { Iran } \\
19 / 02 / 2020- \\
19 / 03 / 2020\end{array}$ & $\begin{array}{l}\text { Epidemic } \\
\text { doubling time }\end{array}$ & 3.5 & $1.3-8.1$ & - \\
\hline $\begin{array}{l}\text { Peirlink et } \\
\text { al. } 2020\end{array}$ & $\begin{array}{l}\text { USA } \\
\text { 21/01/2020- } \\
04 / 04 / 2020\end{array}$ & $\begin{array}{l}\text { SEIR } \\
\text { compertmental } \\
\text { model }\end{array}$ & 5.3 & $4.35-6.25$ & $311357(\mathrm{C})$ \\
\hline $\begin{array}{l}\text { Riou and } \\
\text { Althaus }\end{array}$ & $\begin{array}{l}\text { Wuhan (China) } \\
\text { 31/01/2020- } \\
29 / 01 / 2020\end{array}$ & Simulation & 2.2 & $1.4-3.8$ & 5997 \\
\hline $\begin{array}{l}\text { Rocklov et } \\
\text { al. } 2020\end{array}$ & $\begin{array}{l}\text { Japan } \\
\text { 21/01/2020- } \\
19 / 02 / 2020\end{array}$ & $\begin{array}{l}\text { Compartmental } \\
\text { model using } \\
\text { Susceptible, } \\
\text { Infected, } \\
\text { Infectious, and } \\
\text { Recovered } \\
\text { (SEIR) model }\end{array}$ & 14.8 & 5.3-19 & $619(\mathrm{C})$ \\
\hline $\begin{array}{l}\text { Russo et } \\
\text { al. } 2020\end{array}$ & $\begin{array}{l}\text { Lombardy } \\
\text { (Italy) } \\
05 / 01 / 2020- \\
09 / 04 / 2020\end{array}$ & $\begin{array}{l}\text { compartmental } \\
\text { Susceptible/Exp } \\
\text { osed/ Infectious/ } \\
\text { Recovered/ Dead } \\
\text { (SEIRD) Model }\end{array}$ & 4.51 & 4.14-4.9 & $143626(\mathrm{C})$ \\
\hline $\begin{array}{l}\text { Sanche et } \\
\text { al. } 2020\end{array}$ & $\begin{array}{l}\text { China CDC } \\
\text { 15/01/2020- } \\
30 / 01 / 2020\end{array}$ & $\begin{array}{l}\text { Hybrid } \\
\text { deterministic- } \\
\text { stochastic SEIR }\end{array}$ & 5.7 & $3.8-8.9$ & $140(\mathrm{C})$ \\
\hline $\begin{array}{l}\text { Shim et al. } \\
2020\end{array}$ & $\begin{array}{l}\text { South Korea } \\
\text { 20/01/2020- } \\
06 / 03 / 2020\end{array}$ & $\begin{array}{l}\text { empirical } \\
\text { reporting delay } \\
\text { distribution and } \\
\text { simulating the } \\
\text { generalised } \\
\text { growth model }\end{array}$ & 1.5 & $1.4-1.6$ & $6284(\mathrm{C})$ \\
\hline $\begin{array}{l}\text { Tang et al. } \\
2020\end{array}$ & $\begin{array}{l}\text { China } \\
\text { 08/12/2019- }\end{array}$ & $\begin{array}{l}\text { Departmental } \\
\text { SEIHR model }\end{array}$ & 3.27 & $2.98-3.58$ & $33(\mathrm{C})$ \\
\hline
\end{tabular}


medRxiv preprint doi: https://doi.org/10.1101/2020.05.13.20100750; this version posted May 16, 2020. The copyright holder for this preprint (which was not certified by peer review) is the author/funder, who has granted medRxiv a license to display the preprint in perpetuity. It is made available under a CC-BY-ND 4.0 International license.

\begin{tabular}{|c|c|c|c|c|c|}
\hline & $04 / 01 / 2020$ & & & & \\
\hline $\begin{array}{l}\text { Tsang and } \\
\text { Bajpai } \\
2020\end{array}$ & $\begin{array}{l}\text { Wuhan } \\
\text { 15/01/2020- } \\
\text { 03/03/2020 }\end{array}$ & $\begin{array}{l}\text { Moments of } \\
\text { Gamma } \\
\text { distribution, } \\
\text { Markov Chain } \\
\text { Monte Carlo } \\
\text { (MCMC) }\end{array}$ & 3.15 & $2.8-3.5$ & - \\
\hline $\begin{array}{l}\text { Wang et } \\
\text { al. } 2020\end{array}$ & $\begin{array}{l}\text { Hubei Province } \\
\text { (China) } \\
17 / 01 / 2020- \\
08 / 02 / 2020\end{array}$ & $\begin{array}{l}\text { Exponential } \\
\text { growth (EG) } \\
\text { method }\end{array}$ & 3.49 & $3.42-3.58$ & - \\
\hline $\begin{array}{l}\text { Wang et } \\
\text { al. } 2020\end{array}$ & $\begin{array}{l}\text { Hubei Province } \\
\text { (China) } \\
17 / 01 / 2020- \\
08 / 02 / 2020\end{array}$ & $\begin{array}{l}\text { Exponential } \\
\text { growth (EG) } \\
\text { method, } \\
\text { Maximum } \\
\text { likelihood } \\
\text { estimation (ML), } \\
\text { Sequential } \\
\text { Bayesian method } \\
\text { (SB) }\end{array}$ & 2.95 & $2.86-3.03$ & \\
\hline $\begin{array}{l}\text { Zhang et } \\
\text { al. } 2020\end{array}$ & $\begin{array}{l}\text { Japan } \\
\text { (Diamond } \\
\text { Princess Cruise } \\
\text { Ship- UK) } \\
\text { 20/01/2020- } \\
\text { 17/02/2020 }\end{array}$ & $\begin{array}{l}\text { Bootstrap } \\
\text { sampling method }\end{array}$ & 2.28 & $2.06-2.52$ & $\begin{array}{r}355(\mathrm{C}) \\
3711(\mathrm{~S})\end{array}$ \\
\hline $\begin{array}{l}\text { Zhao et al. } \\
2020\end{array}$ & $\begin{array}{l}\text { China } \\
01 / 01 / 2020- \\
15 / 01 / 2020\end{array}$ & $\begin{array}{l}\text { exponential } \\
\text { growth model } \\
\text { (Long duration) }\end{array}$ & 2.56 & $2.49-2.63$ & $2066(\mathrm{C})$ \\
\hline $\begin{array}{l}\text { Zhao et al. } \\
2020\end{array}$ & $\begin{array}{l}\text { China } \\
\text { 10/01/2020- } \\
24 / 01 / 2020\end{array}$ & $\begin{array}{l}\text { exponential } \\
\text { growth model } \\
\text { (Short duration) }\end{array}$ & 2.24 & $1.96-2.55$ & - \\
\hline $\begin{array}{l}\text { Zhou et al. } \\
2020\end{array}$ & $\begin{array}{l}\text { China } \\
\text { 10/01/2020- } \\
\text { 31/01/2020 }\end{array}$ & $\begin{array}{l}\text { Dynamic } \\
\text { compartmental } \\
\text { model, Basic } \\
\text { SEIR model }\end{array}$ & 5.316 & & $\begin{array}{r}118(\mathrm{C}) \\
11081000 \\
(\mathrm{~S})\end{array}$ \\
\hline $\begin{array}{l}\text { Zhu et al. } \\
2020\end{array}$ & $\begin{array}{l}\text { China CDC } \\
01 / 12 / 2019- \\
\text { 23/01/2020 }\end{array}$ & $\begin{array}{l}\text { MLE estimation, } \\
\text { Poisson }\end{array}$ & 2.54 & $2.49-2.6$ & $\begin{array}{l}3442(\mathrm{C}) \\
8348(\mathrm{~S})\end{array}$ \\
\hline
\end{tabular}


medRxiv preprint doi: https://doi.org/10.1101/2020.05.13.20100750; this version posted May 16, 2020. The copyright holder for this preprint (which was not certified by peer review) is the author/funder, who has granted medRxiv a license to display the preprint in perpetuity. It is made available under a CC-BY-ND 4.0 International license .

\begin{tabular}{|l|l|l|r|r|r|}
\hline & $\begin{array}{l}\text { transmission } \\
\text { model }\end{array}$ & 2.6 & $2.3-2.9$ & $6088(\mathrm{C})$ \\
\hline $\begin{array}{l}\text { Zhuang et } \\
\text { al. } 2020\end{array}$ & $\begin{array}{l}\text { Korea } \\
20 / 01 / 2020- \\
05 / 03 / 2020\end{array}$ & stochastic model & & & \\
\hline $\begin{array}{l}\text { Zhuang et } \\
\text { al. 2020 }\end{array}$ & $\begin{array}{l}\text { Italy } \\
06 / 02 / 2020- \\
05 / 03 / 2020\end{array}$ & stochastic model & 3.2 & $2.9-3.5$ & $3142(\mathrm{C})$ \\
\hline \multicolumn{2}{|l}{ Overall Mean Ro with 95\% CI } & $\mathbf{3 . 7 2}$ & $\mathbf{3 . 4 3 - 4 . 0 4}$ & $\mathbf{3 0}$ \\
\hline
\end{tabular}

Note: Unit of $\mathrm{R}_{0}$ is expressed in persons. 
medRxiv preprint doi: https://doi.org/10.1101/2020.05.13.20100750; this version posted May 16, 2020. The copyright holder for this preprint (which was not certified by peer review) is the author/funder, who has granted medRxiv a license to display the preprint in perpetuity. It is made available under a CC-BY-ND 4.0 International license .

Table 2: Characteristics of included studies in the meta-analysis for CFR

\begin{tabular}{|c|c|c|c|c|c|}
\hline $\begin{array}{l}\text { Author/ } \\
\text { Study }\end{array}$ & $\begin{array}{l}\text { Region/ } \\
\text { Period } \\
\text { (Date/Month/ } \\
\text { Year) }\end{array}$ & Methodology & $\begin{array}{l}\text { Case } \\
\text { fatality } \\
\text { rate } \\
\text { (CFR) }\end{array}$ & $\begin{array}{l}95 \% \\
\text { Confidence } \\
\text { Interval } \\
\text { (CI) }\end{array}$ & $\begin{array}{l}\text { Deaths/ } \\
\text { Confirmed } \\
\text { cases }\end{array}$ \\
\hline $\begin{array}{l}\text { Amariles et } \\
\text { al. } 2020\end{array}$ & $\begin{array}{l}\text { Europe } \\
\text { 06/03/2020- } \\
\text { 18/03/2020 }\end{array}$ & $\begin{array}{l}\text { Stochastic } \\
\text { differential } \\
\text { evolution } \\
\text { algorithm, SIRD } \\
\text { model }\end{array}$ & 4.3 & $0.30-8.30$ & $4664 / 88850$ \\
\hline $\begin{array}{l}\text { Amariles et } \\
\text { al. } 2020\end{array}$ & $\begin{array}{l}\text { Latin America } \\
\text { 06/03/2020- } \\
\text { 18/03/2020 }\end{array}$ & $\begin{array}{l}\text { Stochastic } \\
\text { differential } \\
\text { evolution } \\
\text { algorithm, SIRD } \\
\text { model }\end{array}$ & 1.95 & $0.80-3.10$ & $14 / 1510$ \\
\hline $\begin{array}{l}\text { Anastassop } \\
\text { oulou et al. } \\
2020\end{array}$ & $\begin{array}{l}\text { Hubei } \\
\text { Province } \\
\text { (China) } \\
\text { 11/01/2020- } \\
\text { 10/02/2020 }\end{array}$ & $\begin{array}{l}\text { Susceptible, } \\
\text { Infected, } \\
\text { Recovered and } \\
\text { Dead (SIRD) } \\
\text { models }\end{array}$ & 2.94 & $2.9-3.0$ & $-1-$ \\
\hline $\begin{array}{l}\text { Bayham et } \\
\text { al. } 2020\end{array}$ & $\begin{array}{l}\text { USA } \\
\text { 15/02/2020- } \\
22 / 03 / 2020\end{array}$ & $\begin{array}{l}\text { Infection } \\
\text { mortality rate, } \\
\text { MCKC } \\
\text { simulations }\end{array}$ & 2.3 & $1.80-2.80$ & - \\
\hline $\begin{array}{l}\text { Chatterjee } \\
\text { et al. } 2020\end{array}$ & $\begin{array}{l}\text { Globally } \\
\text { 01/12/2019- } \\
\text { 28/02/2020 }\end{array}$ & $\begin{array}{l}\text { Descriptive: } \\
\text { Adjusted fatality } \\
\text { rate }\end{array}$ & 3.41 & $3.29-3.54$ & $2859 / 83704$ \\
\hline $\begin{array}{l}\mathrm{Fu} \text { et al. } \\
2020\end{array}$ & $\begin{array}{l}\text { Overall } \\
--\end{array}$ & $\begin{array}{l}\text { Systematic } \\
\text { review/Meta- } \\
\text { analysis }\end{array}$ & 3.6 & $1.1-7.2$ & $43 /-$ \\
\hline $\begin{array}{l}\text { Geldsetzer } \\
2020\end{array}$ & USA & $\begin{array}{l}\text { Rapid online } \\
\text { Surveys/comput } \\
\text { e }\end{array}$ & 5 & $2.0-15.0$ & $-/ 1924$ \\
\hline $\begin{array}{l}\text { Geldsetzer } \\
2020\end{array}$ & UK & $\begin{array}{l}\text { Rapid online } \\
\text { Surveys/comput } \\
\text { e }\end{array}$ & 3 & $2.00-10.0$ & $-/ 1540$ \\
\hline
\end{tabular}


medRxiv preprint doi: https://doi.org/10.1101/2020.05.13.20100750; this version posted May 16, 2020. The copyright holder for this preprint (which was not certified by peer review) is the author/funder, who has granted medRxiv a license to display the preprint in perpetuity. It is made available under a CC-BY-ND 4.0 International license .

\begin{tabular}{|c|c|c|c|c|c|}
\hline $\begin{array}{l}\text { Jung et al. } \\
2020\end{array}$ & $\begin{array}{l}\text { China (Fixed } \\
\text { starting point) } \\
\text { 08/12/2019- } \\
\text { 24/01/2020 }\end{array}$ & $\begin{array}{l}\text { Delay } \\
\text { distributions } \\
\text { with fixed } \\
\text { starting point, } \\
\text { MCMC }\end{array}$ & 5.3 & $3.5-7.5$ & $41 /-$ \\
\hline $\begin{array}{l}\text { Jung et al. } \\
2020\end{array}$ & $\begin{array}{l}\text { China } \\
\text { (Varying } \\
\text { starting point) } \\
\text { 13/01/2020- } \\
24 / 01 / 2020\end{array}$ & $\begin{array}{l}\text { Delay } \\
\text { distributions } \\
\text { variable starting } \\
\text { point, MCMC }\end{array}$ & 8.4 & $5.3-12.3$ & $41 /-$ \\
\hline $\begin{array}{l}\text { Kobayashi } \\
\text { et al. } 2020\end{array}$ & $\begin{array}{l}\text { Hubei } \\
\text { 31/12/2020- } \\
14 / 02 / 2020\end{array}$ & $\begin{array}{l}\text { Descriptive: } \\
\text { Adjusted fatality } \\
\text { rate }\end{array}$ & 18 & $11-81$ & - \\
\hline $\begin{array}{l}\text { Kobayashi } \\
\text { et al. } 2020\end{array}$ & $\begin{array}{l}\text { Outside } \\
\text { mainland } \\
\text { China } \\
\text { 31/12/2020- } \\
\text { 14/02/2020 }\end{array}$ & $\begin{array}{l}\text { Descriptive: } \\
\text { Adjusted fatality } \\
\text { rate }\end{array}$ & 2.5 & $1-85$ & - \\
\hline $\begin{array}{l}\text { Kobayashi } \\
\text { et al. } 2020\end{array}$ & $\begin{array}{l}\text { Hubei } \\
5 \text { days }\end{array}$ & $\begin{array}{l}\text { Descriptive: } \\
\text { Infection fatality } \\
\text { risk }\end{array}$ & 0.27 & $0.19-0.38$ & \\
\hline $\begin{array}{ll}\text { Michael } & \\
\text { Arieh } & \text { P. } \\
\text { Medina } & \\
2020 & \end{array}$ & $\begin{array}{l}\text { Philippines } \\
\text { 08/03/2020- } \\
\text { 06/04/2020 }\end{array}$ & $\begin{array}{l}\text { simple linear } \\
\text { regression } \\
\text { model }\end{array}$ & 4.35 & $4.12-4.55$ & $163 / 3000$ \\
\hline $\begin{array}{l}\text { Mizumoto } \\
\text { and } \\
\text { Chowell } \\
2020\end{array}$ & $\begin{array}{l}\text { China } \\
01 / 01 / 2020- \\
11 / 02 / 2020\end{array}$ & $\begin{array}{l}\text { Delay models, } \\
\text { MCKC, } \\
\text { Bayesian } \\
\text { framework }\end{array}$ & 12.2 & $11.3-13.1$ & $\begin{array}{r}\text { Rolling/111 } \\
7\end{array}$ \\
\hline $\begin{array}{l}\text { Öztoprak } \\
\text { and Javed }\end{array}$ & $\begin{array}{l}\text { Turkey } \\
\text { 16/03/2020- } \\
31 / 03 / 2020\end{array}$ & $\begin{array}{l}\text { linear regression } \\
\text { analysis }\end{array}$ & 1.85 & $1.51-2.18$ & $314 / 13531$ \\
\hline $\begin{array}{l}\text { Öztoprak } \\
\text { and Javed }\end{array}$ & $\begin{array}{l}\text { France } \\
16 / 03 / 2020- \\
31 / 03 / 2020\end{array}$ & $\begin{array}{l}\text { linear regression } \\
\text { analysis }\end{array}$ & 1.979 & $1.79-2.15$ & $48 / 2281$ \\
\hline $\begin{array}{l}\text { Russell et } \\
\text { al. } 2020\end{array}$ & $\begin{array}{l}\text { Japan } \\
\text { 05/02/2020- }\end{array}$ & $\begin{array}{l}\text { Age } \\
\text { standardisation }\end{array}$ & 2.6 & $0.89-6.70$ & $7 / 705$ \\
\hline
\end{tabular}


medRxiv preprint doi: https://doi.org/10.1101/2020.05.13.20100750; this version posted May 16, 2020. The copyright holder for this preprint (which was not certified by peer review) is the author/funder, who has granted medRxiv a license to display the preprint in perpetuity. It is made available under a CC-BY-ND 4.0 International license.

\begin{tabular}{|c|c|c|c|c|c|}
\hline & $04 / 03 / 2020$ & & & & \\
\hline $\begin{array}{l}\text { Shim et al. } \\
2020\end{array}$ & $\begin{array}{l}\text { South Korea } \\
20 / 01 / 2020- \\
26 / 02 / 2020\end{array}$ & $\begin{array}{l}\text { Generalised } \\
\text { growth model }\end{array}$ & 0.7 & $0.4-1.1$ & $42 / 6284$ \\
\hline $\begin{array}{l}\text { Verity et al. } \\
2020\end{array}$ & $\begin{array}{l}\text { China } \\
\text { 01/01/2020- } \\
\text { 08/02/2020 }\end{array}$ & $\begin{array}{l}\text { Bayesian } \\
\text { Marko-Chain } \\
\text { Monte Carlo } \\
\text { (Adjusted for } \\
\text { censoring) }\end{array}$ & 3.67 & 3.56- 3.8 & $24 / 70117$ \\
\hline $\begin{array}{l}\text { Verity et al. } \\
2020\end{array}$ & $\begin{array}{l}\text { China } \\
\text { 01/01/2020- } \\
\text { 08/02/2020 }\end{array}$ & $\begin{array}{l}\text { Bayesian } \\
\text { Marko-Chain } \\
\text { Monte Carlo } \\
\text { (Demographic } \\
\text { adjustment) }\end{array}$ & 1.38 & $1.23-1.53$ & $24 / 70117$ \\
\hline $\begin{array}{l}\text { Wang et al. } \\
2020\end{array}$ & $\begin{array}{l}\text { China } \\
\text { 15/01/2020- } \\
11 / 03 / 2020\end{array}$ & $\begin{array}{l}\text { binomial } \\
\text { probability } \\
\text { method }\end{array}$ & 3.9 & $3.80-4.10$ & $3169 / 80793$ \\
\hline $\begin{array}{l}\text { Wang et al. } \\
2020\end{array}$ & $\begin{array}{l}\text { China outside } \\
\text { of Hubei } \\
15 / 01 / 2020- \\
11 / 03 / 2020\end{array}$ & $\begin{array}{l}\text { binomial } \\
\text { probability } \\
\text { method }\end{array}$ & 0.87 & $0.72-1.00$ & $3169 / 80793$ \\
\hline $\begin{array}{l}\text { Wang et al. } \\
2020\end{array}$ & $\begin{array}{l}\text { China } \\
\text { 15/01/2020- } \\
11 / 03 / 2020\end{array}$ & $\begin{array}{l}\text { survival analysis } \\
\text { method }\end{array}$ & 4.6 & $4.40-4.70$ & $3169 / 80793$ \\
\hline $\begin{array}{l}\text { Wang et al. } \\
2020\end{array}$ & $\begin{array}{l}\text { China outside } \\
\text { of Hubei } \\
15 / 01 / 2020- \\
11 / 03 / 2020\end{array}$ & $\begin{array}{l}\text { survival analysis } \\
\text { method }\end{array}$ & .92 & $0.76-1.10$ & $3169 / 80793$ \\
\hline $\begin{array}{l}\text { Wilson et al. } \\
2020\end{array}$ & $\begin{array}{l}\text { China } \\
\text { 21/02/2020- } \\
\text { 05/03/2020 }\end{array}$ & $\begin{array}{l}\text { Time-delay } \\
\text { adjusted case- } \\
\text { fatality risk }\end{array}$ & 3.5 & $3.35-3.61$ & $2624 / 75569$ \\
\hline $\begin{array}{l}\text { Wilson et al. } \\
2020\end{array}$ & $\begin{array}{l}82 \text { countries } \\
21 / 02 / 2020- \\
05 / 03 / 2020\end{array}$ & $\begin{array}{l}\text { Time-delay } \\
\text { adjusted case- } \\
\text { fatality risk }\end{array}$ & 4.2 & $2.58-6.87$ & $15 / 354$ \\
\hline
\end{tabular}


medRxiv preprint doi: https://doi.org/10.1101/2020.05.13.20100750; this version posted May 16, 2020. The copyright holder for this preprint (which was not certified by peer review) is the author/funder, who has granted medRxiv a license to display the preprint in perpetuity. It is made available under a CC-BY-ND 4.0 International license .

\begin{tabular}{|l|l|l|r|r|r|}
\hline $\begin{array}{l}\text { Yang et al. } \\
2020\end{array}$ & $\begin{array}{l}\text { China } \\
10 / 01 / 2020- \\
03 / 02 / 2020\end{array}$ & $\begin{array}{l}\text { Linear } \\
\text { regression }\end{array}$ & 2.1 & $2.05-2.14$ & $-/-$ \\
\hline $\begin{array}{l}\text { Yang et al. } \\
2020\end{array}$ & $\begin{array}{l}\text { Hubei } \\
10 / 01 / 2020- \\
03 / 02 / 2020\end{array}$ & $\begin{array}{l}\text { Linear } \\
\text { regression }\end{array}$ & 1.41 & $1.38-1.45$ & $-/-$ \\
\hline
\end{tabular}

Note: Unit of CFR is expressed in per cent. 
medRxiv preprint doi: https://doi.org/10.1101/2020.05.13.20100750; this version posted May 16, 2020. The copyright holder for this preprint (which was not certified by peer review) is the author/funder, who has granted medRxiv a license to display the preprint in perpetuity. It is made available under a CC-BY-ND 4.0 International license .

Table 3: Test of heterogeneity for sample in a meta-analysis

\begin{tabular}{|l|r|r|}
\hline Test of Heterogeneity & \multicolumn{2}{|c|}{ Ro } \\
\hline$I^{2}$ statistic & $(99.9 \%-99.9 \%)$ & \multicolumn{2}{c|}{ CFR } \\
\hline Tau-squared $\left(\tau^{2}\right)$ & 2.42 & $99.7 \%$ \\
\hline Cochran's Q statistics & $(0.84-4.75)$ & $(1.06-5.81)$ \\
\hline n & $22701.5 *$ & $7657.4^{*}$ \\
\hline
\end{tabular}

Source: Own calculations

*: significant at $95 \%$ of confidence interval

Table 4: Overall effect size based on various methods for $R_{0}$

\begin{tabular}{|c|c|c|c|c|c|c|}
\hline \multirow{3}{*}{ Model } & \multicolumn{3}{|c|}{ All data $(n=30)$} & \multicolumn{3}{|c|}{ Excluding outliers $(n=28)$} \\
\hline & $\begin{array}{c}\text { Inverse } \\
\text { variance } \\
\text { method }\end{array}$ & $\begin{array}{l}\text { Fixed- } \\
\text { effects } \\
\text { model }\end{array}$ & $\begin{array}{l}\text { Random- } \\
\text { effects } \\
\text { model }\end{array}$ & $\begin{array}{c}\text { Inverse } \\
\text { variance } \\
\text { method }\end{array}$ & $\begin{array}{l}\text { Fixed- } \\
\text { effects } \\
\text { model }\end{array}$ & $\begin{array}{c}\text { Random- } \\
\text { effects } \\
\text { model }\end{array}$ \\
\hline & (a) & (b) & (c) & (d) & (e) & (f) \\
\hline $\begin{array}{l}\text { Overall } \\
\text { effect } \\
\text { size } \\
\text { (persons) }\end{array}$ & $\begin{array}{c}3.72 \\
(3.43- \\
4.04)\end{array}$ & $\begin{array}{r}3.36 \\
(3.35- \\
3.38)\end{array}$ & $\begin{array}{c}3.39 \\
(2.79- \\
3.98)\end{array}$ & $\begin{array}{c}3.21 \\
(2.90- \\
3.54)\end{array}$ & $\begin{array}{c}3.36 \\
(3.35- \\
3.38)\end{array}$ & $\begin{array}{c}3.11 \\
(2.49- \\
3.71)\end{array}$ \\
\hline
\end{tabular}

Source: Own calculations. Unit of $\mathrm{R}_{0}$ is expressed in persons.

Note: Random-effects models gives the best estimate after accounting for heterogeneity in studies; Estimates from fixed-effects model and inverse variance method are shown for comparison.

Table 5: Overall effect size based on various methods for CFR

\begin{tabular}{|l|r|r|r|r|r|r|}
\hline \multirow{4}{*}{ Model } & \multicolumn{3}{|c|}{ All data (n=28) } & \multicolumn{3}{c|}{ Excluding outliers (n=24) } \\
\cline { 2 - 7 } & $\begin{array}{c}\text { Inverse } \\
\text { variance } \\
\text { method }\end{array}$ & $\begin{array}{c}\text { Fixed- } \\
\text { effects } \\
\text { model }\end{array}$ & $\begin{array}{c}\text { Random- } \\
\text { effects } \\
\text { model }\end{array}$ & $\begin{array}{l}\text { Inverse } \\
\text { variance } \\
\text { method }\end{array}$ & $\begin{array}{c}\text { Fixed- } \\
\text { effects } \\
\text { model }\end{array}$ & $\begin{array}{c}\text { Random- } \\
\text { effects } \\
\text { model }\end{array}$ \\
\cline { 2 - 7 } & (a) & $($ b) & $(\mathbf{c})$ & (d) & $($ e) & (f) \\
\hline $\begin{array}{l}\text { Overall } \\
\text { effect } \\
\text { size }\end{array}$ & 3.96 & 2.17 & 3.20 & 2.79 & 2.16 & 2.63 \\
(per cent) & $(3.67-$ & $(2.15-$ & $(2.76-$ & $(2.58-$ & $(2.14-$ & $(2.18-$ \\
$2.19)$ & $3.64)$ & $3.02)$ & $2.18)$ & $3.08)$ \\
\hline
\end{tabular}

Source: Own calculations; Unit of CFR is expressed in per cent.

Note: Random-effects models gives the best estimate after accounting for heterogeneity in studies; Estimates from fixed-effects model and inverse variance method are shown for comparison. 
medRxiv preprint doi: https://doi.org/10.1101/2020.05.13.20100750; this version posted May 16, 2020. The copyright holder for this preprint (which was not certified by peer review) is the author/funder, who has granted medRxiv a license to display the preprint in perpetuity. It is made available under a CC-BY-ND 4.0 International license .

Table 6: Effect size and test of heterogeneity for $R_{0}$ by region and overall

\begin{tabular}{|c|c|c|c|c|c|}
\hline \multirow[t]{2}{*}{ Statistics } & \multicolumn{3}{|c|}{ Region } & \multirow{2}{*}{$\begin{array}{c}\text { Test for } \\
\text { Subgroup } \\
\text { differences }\end{array}$} & \multirow[b]{2}{*}{ Overall } \\
\hline & $\begin{array}{l}\text { China and } \\
\text { its } \\
\text { provinces }\end{array}$ & $\begin{array}{l}\text { Other Asian } \\
\text { countries }\end{array}$ & $\begin{array}{l}\text { Other } \\
\text { countries }\end{array}$ & & \\
\hline $\begin{array}{l}\text { Effect Size } \\
\text { (random-effects } \\
\text { model) }\end{array}$ & $\begin{array}{r}3.21 \\
(2.73-3.68)\end{array}$ & $\begin{array}{r}1.90 \\
(1.06-2.73)\end{array}$ & $\begin{array}{r}3.83 \\
(2.44-5.21)\end{array}$ & \multirow{5}{*}{$\begin{array}{c}8.67 \\
\text { (p-value } \\
=0.013)\end{array}$} & $\begin{array}{r}3.11 \\
(2.50-3.72)\end{array}$ \\
\hline$I^{2}$ statistic & $99.7 \%$ & $99.5 \%$ & $98.4 \%$ & & $99.9 \%$ \\
\hline Tau-squared & - & - & - & & $\begin{array}{r}2.42 \\
(0.72-4.12)\end{array}$ \\
\hline $\begin{array}{l}\text { Cochran's Q } \\
\text { statistics }\end{array}$ & - & - & - & & $22639.5^{*}$ \\
\hline n $($ sample $=28)$ & 16 & 5 & 7 & & 28 \\
\hline
\end{tabular}

Source: Own calculations $(\mathrm{n}=28)$ excluding outliers. The estimates are based on random-effects model. *: significant at $95 \%$ confidence interval; Unit of $\mathrm{R}_{0}$ is expressed in persons.

Note:

(1) Other Asian countries include studies based on data from Japan and Korea

(2) Other countries include studies based on data from Nigeria, Iran, Italy, and the USA

Table 7: Effect size and test of heterogeneity for CFR by region and overall

\begin{tabular}{|c|c|c|c|c|c|}
\hline \multirow[b]{2}{*}{ Statistics } & \multicolumn{3}{|c|}{ Region } & \multirow{2}{*}{$\begin{array}{c}\text { Test for } \\
\text { Subgroup } \\
\text { differences }\end{array}$} & \multirow{2}{*}{ Overall } \\
\hline & $\begin{array}{l}\text { China and } \\
\text { its provinces }\end{array}$ & $\begin{array}{c}\text { Other Asian } \\
\text { countries }\end{array}$ & $\begin{array}{l}\text { Other } \\
\text { countries }\end{array}$ & & \\
\hline Effect Size & 2.53 & 2.55 & 2.77 & \multirow{6}{*}{$\begin{array}{c}0.22 \\
(p-\text { value } \\
=0.868)\end{array}$} & 2.63 \\
\hline $\begin{array}{l}\text { (random-effects } \\
\text { model) }\end{array}$ & $(1.91-3.14)$ & $(-0.37-5.46)$ & $(2.07-3.47)$ & & $(2.18-3.08)$ \\
\hline$I^{2}$ statistic & $99.9 \%$ & $99.4 \%$ & $95.9 \%$ & & $99.7 \%$ \\
\hline Tau-squared & - & - & - & & $\begin{array}{r}1.06 \\
(0.61-3.48)\end{array}$ \\
\hline $\begin{array}{l}\text { Cochran's Q } \\
\text { statistics }\end{array}$ & - & - & - & & $8060.72 *$ \\
\hline n $($ sample $=24)$ & 11 & 3 & 10 & & 24 \\
\hline
\end{tabular}

Source: Own calculations $(\mathrm{n}=24)$ excluding outliers. The estimates are based on random-effects model.

*: significant at $95 \%$ confidence interval; Unit of CFR is expressed in per cent.

Note:

(1) Other Asian countries include studies based on data from Japan, South Korea, and Philippines

(2) Other countries include studies based on data from Europe, France, Latin America, Turkey, the UK, and the USA 
medRxiv preprint doi: https://doi.org/10.1101/2020.05.13.20100750; this version posted May 16, 2020. The copyright holder for this preprint (which was not certified by peer review) is the author/funder, who has granted medRxiv a license to display the preprint in perpetuity. It is made available under a CC-BY-ND 4.0 International license .

\section{Figures}

Figure 1: Forest plot of $R_{0}$ values based on random-effects model, by regional subgroups

\section{Source}

Group = China and its provinces

Jung et al. ø China

Tang et. al. $ø$ China

Zhou et al. ø China

Zhao et al. ø China (Long duration)

Zhao et al. ø China (Short duration)

Sanche et al. ø China CDC

Zhu et al. $ø$ China CDC

Choi and $\mathrm{Ki} ø$ Hubei Province

Boldog et al. ø Hubei Province

Wang et al. ø Hubei Province (Bayesian)

Wang et al. ø Hubei Province (Exponential)

Anastassopoulou et al. ø Hubei Province (Short interval)

Lai et al. ø mainland China

Kucharski et. al. $ø$ Wuhan

Tsang et al. $ø$ Wuhan

Riou and Althaus $ø$ Wuhan

Total

Heterogeneity: $\chi_{15}^{2}=4342.03(P<.001), I^{2}=100 \%$

Group = Other Asian countries

Zhang et al. ø Diamond Princess Cruise Ship-UK

Kuniya ø Japan

Choi and $\mathrm{Ki} ø$ Korea

Zhuang et al. ø Korea

Shim et al. ø South Korea

Total

Heterogeneity: $\chi_{4}^{2}=872.47(P<.001), I^{2}=100 \%$

Group = Other countries

Muniz-Rodriguez et al. ø Iran (Epidemiological doubling time) $3.50[-1.10 ; 8.10]$

Muniz-Rodriguez et al. ø Iran (Generalized growth model)

Zhuang et al. ø Italy

Russo et al. ø Lombardy (Italy)

Adegboye et al. $\varnothing$ Nigeria (Long interval)

Adegboye et al. $\varnothing$ Nigeria (Short interval)

Peirlink et al. ø USA

Total

Heterogeneity: $\chi_{6}^{2}=382.53(P<.001), I^{2}=98 \%$

Total

Prediction interval

Heterogeneity: $\chi_{27}^{2}=22639.56(P<.001), l^{2}=100 \%$

Residual heterogeneity: $\chi_{25}^{2}=5597.04(P<.001), I^{2}=100 \%$

\section{SMD $(95 \% \mathrm{Cl})$}

$3.20[2.70 ; 3.70]$

$3.27[2.96 ; 3.58]$

$5.32[4.92 ; 5.71]$

$2.56[2.49 ; 2.63]$

$2.24[1.93 ; 2.55]$

$5.70[2.50 ; 8.90]$

$2.54[2.48 ; 2.60]$

$4.03[4.01 ; 4.05]$

$2.60[2.10 ; 3.10]$

$2.95[2.87 ; 3.03]$

$3.49[3.40 ; 3.58]$

$4.80[2.93 ; 6.67]$

$2.68[2.50 ; 2.86]$

$2.35[-0.07 ; 4.77]$

$3.15[2.80 ; 3.50]$

$3.21[2.73 ; 3.68]$

$2.28[2.04 ; 2.52]$

$2.60[2.40 ; 2.80]$

$0.56[0.51 ; 0.60]$

$2.60[2.30 ; 2.90]$

$1.50[1.40 ; 1.60]$

$1.90[1.06 ; 2.74]$

$4.40[3.90 ; 4.90]$

$3.20[2.90 ; 3.50]$

$4.51[4.12 ; 4.90]$

$1.42[1.26 ; 1.58]$

$4.98[1.55 ; 8.41]$

$5.30[4.35 ; 6.25]$

$3.83[2.44 ; 5.22]$

3.11 [ $2.50 ; 3.72]$

$[-0.15 ; 6.37]$
$2.20[0.60 ; 3.80]$

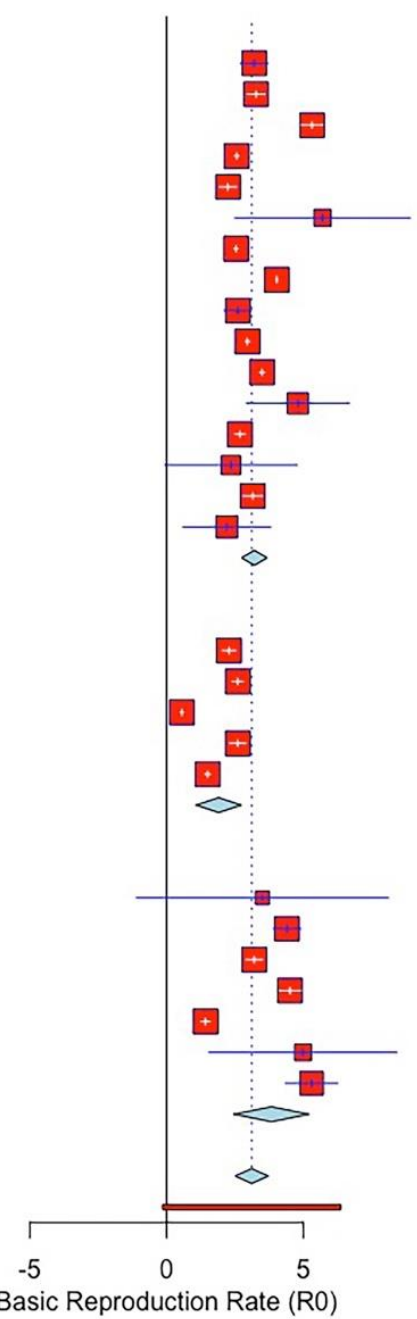

Basic Reproduction Rate (R0)

Source: Own calculation; $n=28$ excluding outliers; Unit of $\mathrm{R}_{0}$ is expressed in persons.

Note:

(1) Other Asian countries include studies based on data from Japan and Korea

(2) Other countries include studies based on data from Nigeria, Iran, the United States of America, and Italy 
medRxiv preprint doi: https://doi.org/10.1101/2020.05.13.20100750; this version posted May 16, 2020. The copyright holder for this preprint (which was not certified by peer review) is the author/funder, who has granted medRxiv a license to display the preprint in perpetuity. It is made available under a CC-BY-ND 4.0 International license .

Figure 2: Forest plot of CFR values based on random-effects model, by regional subgroups

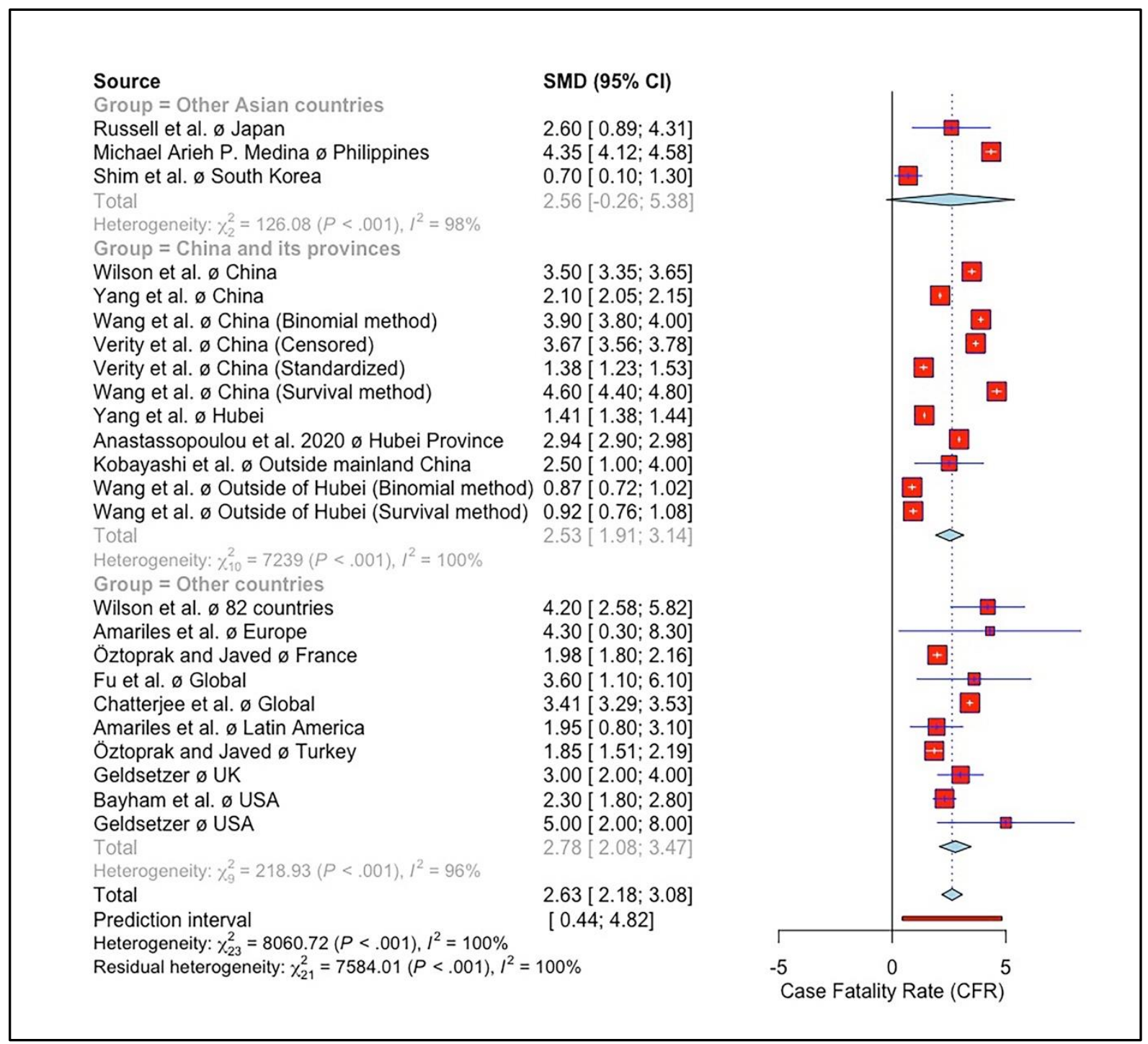

Source: Own calculations ( $\mathrm{n}=24)$ excluding outliers; Unit of CFR is expressed in per cent.

Note:

(1) Other Asian countries include studies based on data from Japan, South Korea, and Philippines

(2) Other countries include studies based on data from Europe, France, Latin America, Turkey, the United Kingdom, and the United States of America 
medRxiv preprint doi: https://doi.org/10.1101/2020.05.13.20100750; this version posted May 16, 2020. The copyright holder for this preprint (which was not certified by peer review) is the author/funder, who has granted medRxiv a license to display the preprint in perpetuity.

Figure 3: Funnel plot for $R_{0}$ values based on random-effects model

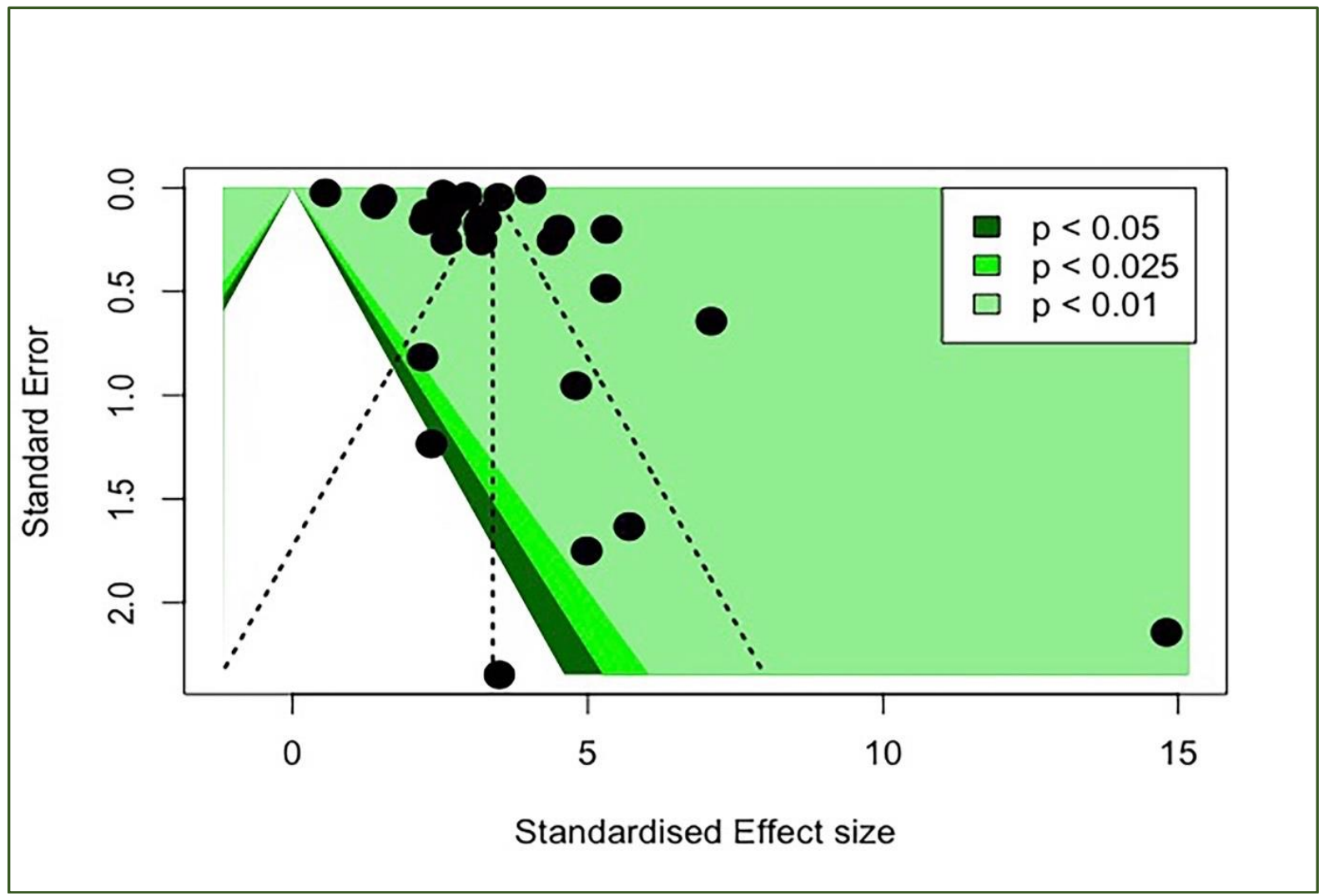

Source: Own calculation; n=30 (all studies); The circles are the selected peer-reviewed articles

Figure 4: Funnel plot for CFR values based on random-effects model

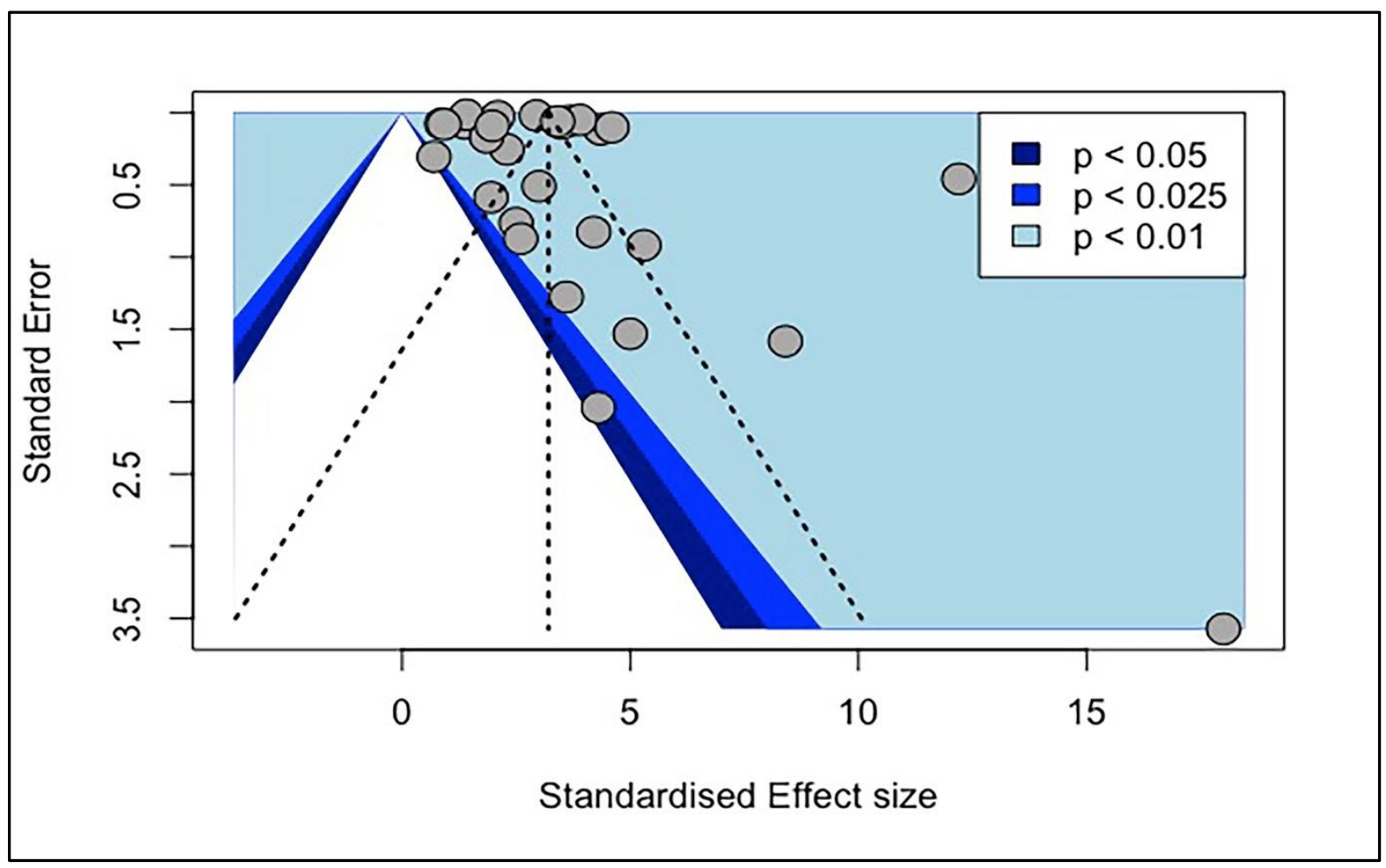

Source: Own calculation; $n=28$ (all studies); The circles are the selected peer-reviewed articles 